Supporting Information

\title{
Blue-Light Photocleavable Protecting Groups based on Benzothiadiazole Scaffolds.
}

\author{
Sean Norris, Caroline C. Warner, Andrea M. Thooft, Selin K. Demirci, Bryan J. Lampkin, Kyle Miner, \\ Arkady Ellern, Brett VanVeller*
}

Department of Chemistry, lowa State University, Ames, lowa 50011

bvv@iastate.edu

Contents

Materials

General Experimental

Synthetic Procedures

NMR Spectra

Figure S1. ${ }^{1} \mathrm{H}$ NMR spectrum of $4\left(\mathrm{CDCl}_{3}, 600 \mathrm{MHz}\right)$

Figure $52 .{ }^{13} \mathrm{C}\{1 \mathrm{H}\}$ NMR spectrum of $4\left(\mathrm{CDCl}_{3}, 150 \mathrm{MHz}\right)$

Figure S3. ${ }^{1} \mathrm{H}$ NMR spectrum of $8\left(\mathrm{CDCl}_{3}, 400 \mathrm{MHz}\right)$

Figure S4. ${ }^{13} \mathrm{C}\{1 \mathrm{H}\}$ NMR spectrum of $8\left(\mathrm{CDCl}_{3}, 150 \mathrm{MHz}\right)$

S8

Figure S5. ${ }^{1} \mathrm{H}$ NMR spectrum of $9\left(\mathrm{CDCl}_{3}, 400 \mathrm{MHz}\right)$.

S9

Figure S6. ${ }^{13} \mathrm{C}\{1 \mathrm{H}\}$ NMR spectrum of $9\left(\mathrm{CD}_{3} \mathrm{OD}, 100 \mathrm{MHz}\right)$

S9

Figure S7. ${ }^{1} \mathrm{H}$ NMR spectrum of $10\left(\mathrm{CDCl}_{3}, 400 \mathrm{MHz}\right)$.

$\mathrm{S} 10$

Figure S8. ${ }^{13} \mathrm{C}\{1 \mathrm{H}\}$ NMR spectrum of $10\left(\mathrm{CDCl}_{3}, 100 \mathrm{MHz}\right)$

S10

Figure S9. Crude ${ }^{1} \mathrm{H}$ NMR spectrum of $14\left(\mathrm{CDCl}_{3}, 400 \mathrm{MHz}\right)$.

S11

Figure S10. Crude ${ }^{1} \mathrm{H}$ NMR spectrum of $15\left(\mathrm{CDCl}_{3}, 400 \mathrm{MHz}\right)$.

Figure S11. ${ }^{1} \mathrm{H}$ NMR spectrum of $16\left(\mathrm{CDCl}_{3}, 400 \mathrm{MHz}\right)$.

Figure $\mathrm{S12}^{13} \mathrm{C}\{1 \mathrm{H}\} \quad \mathrm{NMR}$ spectrum of $16\left(\mathrm{CDCl}_{3}, 100 \mathrm{MHz}\right)$

Figure S13. ${ }^{1 \mathrm{H}} \mathrm{NMR}$ spectrum of $17\left(\mathrm{CDCl}_{3}, 400 \mathrm{MHz}\right)$.

Figure $514 .{ }^{13} \mathrm{C}\{1 \mathrm{H}\} \quad \mathrm{NMR}$ spectrum of $17\left(\mathrm{CDCl}_{3}, 100 \mathrm{MHz}\right)$

Figure S15. ${ }^{1 \mathrm{H}} \mathrm{NMR}$ spectrum of $18\left(\mathrm{CDCl}_{3}, 400 \mathrm{MHz}\right)$.

$\mathrm{S} 14$

Figure $516 .{ }^{13} \mathrm{C}\{1 \mathrm{H}\}$ NMR spectrum of $18\left(\mathrm{CDCl}_{3}, 100 \mathrm{MHz}\right)$

$\mathrm{S} 14$

Figure S17. ${ }^{1 \mathrm{H}} \mathrm{NMR}$ spectrum of $11\left(\mathrm{CDCl}_{3}, 400 \mathrm{MHz}\right)$.

Figure $518 .{ }^{13} \mathrm{C}\{1 \mathrm{H}\} \quad \mathrm{NMR}$ spectrum of $11\left(\mathrm{CDCl}_{3}, 100 \mathrm{MHz}\right)$

Figure S19. ${ }^{1 \mathrm{H}} \mathrm{NMR}$ spectrum of $12\left(\mathrm{CDCl}_{3}, 400 \mathrm{MHz}\right)$.

$\mathrm{S} 16$

Figure $\mathrm{S20}^{13} \mathrm{C}\{1 \mathrm{H}\}$ NMR spectrum of $12\left(\mathrm{CDCl}_{3}, 100 \mathrm{MHz}\right)$

Representative Irradiation Trials

Figure S21: Representative ${ }^{1} \mathrm{H}$ NMR of irradiated BODIPY

Figure S22: Representative ${ }^{1} \mathrm{H}$ NMR of irradiated 8

Figure S23: Representative ${ }^{1} \mathrm{H}$ NMR of irradiated 9

Figure S24: Representative ${ }^{1} \mathrm{H}$ NMR of irradiated 10

$\mathrm{S} 23$

Figure S25: Representative ${ }^{1} \mathrm{H}$ NMR of irradiated 11

S24

Figure S26: Representative ${ }^{1} \mathrm{H}$ NMR of irradiated 12

S25

Computed Structures 
Photophysical Data for Molecules 8-12

UPLC Traces of molecules 9 and $12 \quad$ S29

Figure S27: UPLC trace of molecule 9

Figure S28: UPLC trace and relative peak integrations of $12 \quad$ S30

UV-vis before and after irradiation spectra for 10

Figure S29: UV-vis absorbance before and after irradiation with $455 \mathrm{~nm}$ LED light $\quad$ S31

Figure S30: UPLC-MS trace of $\mathbf{1 0}$ before irradiation with $455 \mathrm{~nm}$ LED light. S31

Figure S31: UPLC-MS trace of 10 at $3 \mathrm{~h}$ (top) and $6 \mathrm{~h}$ (bottom) of irradiation with $455 \mathrm{~nm} \quad$ S32 LED light.

References

S31

Materials: Unless otherwise specified, all commercial products and reagents were used as purchased, without further purification. Analytical thin-layer chromatography (TLC) and flash chromatography of all reactions was performed on silica gel $(40 \mu \mathrm{m})$ purchased from Grace Davison. All solvents used for photophysical experiments were reagent grade.

\section{Experimental:}

NMR Spectroscopy: ${ }^{1} \mathrm{H}$ and ${ }^{13} \mathrm{C}$ NMR spectra for all compounds were acquired in deuterated solvents (as indicated) on a Bruker Spectrometer at the field strengths reported in the text. The chemical shift data are reported in units of $\delta(\mathrm{ppm})$ relative to residual solvent.

Absorption Spectroscopy: Ultraviolet-visible absorption spectra were measured with an Agilent Technologies Cary 8454 UV-Vis Diode Array System and corrected for background signal with a cuvette containing the same solvent used for analysis.

Photocleavage studies: Photolysis studies were carried out in a quartz cuvette or standard NMR tube using a Luzchem ${ }^{\circledR}$ LED Illuminator $(455 \mathrm{~nm})$ photoreactor. Samples were irradiated for the times indicated. 


\section{Synthetic Procedures}<smiles>Cc1cc(Br)c2nsnc2c1[N+](=O)[O-]</smiles>

Synthesis of 4: 7-bromo-5-methyl-4-nitrobenzothiadiazole ${ }^{1}(0.10 \mathrm{~g}, 0.36 \mathrm{mmol}, 1 \mathrm{eq})$ was dissolved in DMF $(1.2 \mathrm{~mL})$ under inert atmosphere. Dimethylformamide-dimethylacetal $(0.11 \mathrm{~mL}, 0.83 \mathrm{mmol}, 2.3 \mathrm{eq})$ was added and heated at $60{ }^{\circ} \mathrm{C}$ in an oil bath for $1.5 \mathrm{~h}$. The reaction was concentrated under reduced pressure. The residue was dissolved in THF $(8 \mathrm{~mL})$ and water $(8 \mathrm{~mL})$ and $\mathrm{NalO}_{4}(1.035 \mathrm{~g}, 4.8 \mathrm{mmol}, 3$ eq) was added. The mixture was stirred at $60^{\circ} \mathrm{C}$ for $1.5 \mathrm{~h}$ and filtered and rinsed with EtOAc. The filtrate was washed with sat. $\mathrm{NaHCO}_{3}(2 \mathrm{x})$. The organic layer was concentrated under reduced pressure and the residue was purified using silica gel chromatography ( $4: 1$ hexanes:EtOAc) to yield $\mathbf{4}$ as an orange powder (0.21 g, 45\% over two steps).

${ }_{1}^{1} \mathrm{HNMR}\left(\mathrm{CDCl}_{3}, 600 \mathrm{MHz}\right) \delta 10.35(\mathrm{~s}, 1 \mathrm{H}), 8.42(\mathrm{~s}, 1 \mathrm{H})$.

${ }^{13} \mathrm{C}\{1 \mathrm{H}\} \mathrm{NMR}\left(\mathrm{CDCl}_{3}, 150 \mathrm{MHz}\right) \delta 185.0,156.0,145.7,128.9(2 \mathrm{C}), 128.8,120.2$.

A molecular ion could not be found. Compound did not ionize for MS analysis but subsequent intermediates could be fully characterized and the final structure was unambiguously characterized by Xray crystallography.<smiles>CN(CC#N)C(=O)c1cc(Br)c2nsnc2c1[N+](=O)[O-]</smiles><smiles>CN(C)c1c(C=O)cc(Br)c2nsnc12</smiles><smiles>[R19]1CCCCC1</smiles><smiles>CC(=O)OCc1cc(Br)c2nsnc2c1N(C)C</smiles>

Synthesis of 8: $4(0.10 \mathrm{~g}, 0.34 \mathrm{mmol}, 1 \mathrm{eq})$ and $\mathrm{Me} 2 \mathrm{NH} \cdot \mathrm{HCl}(0.060 \mathrm{~g}, 0.68 \mathrm{mmol}, 2 \mathrm{eq})$ were dissolved in acetonitrile $(1.8 \mathrm{~mL})$. Triethylamine $(0.20 \mathrm{~mL}, 1.44 \mathrm{mmol}, 4 \mathrm{eq})$ was added and the solution was stirred at $60{ }^{\circ} \mathrm{C}$ for $1 \mathrm{~h}$. The reaction was diluted with EtOAc, washed with water, and the organic fraction was dried over $\mathrm{Na}_{2} \mathrm{SO}_{4}$ concentrated under reduced pressure to yield 7 , which was immediately dissolved in THF $(1.1 \mathrm{~mL})$ and $\mathrm{NaBH}_{4}(0.015 \mathrm{~g}, 0.34 \mathrm{mmol}, 1 \mathrm{eq})$ was added. The mixture was stirred for $22 \mathrm{~h}$ at room temperature and was partitioned between $\mathrm{DCM}$ and water. The organic layer was dried over $\mathrm{Na}_{2} \mathrm{SO}_{4}$ and concentrated under reduced pressure to yield $\mathbf{7 b}$, which was dissolved in a mixture of pyridine $(0.22 \mathrm{~mL}$, $2.72 \mathrm{mmol}, 8 \mathrm{eq})$ and $\mathrm{DCM}(1.7 \mathrm{~mL})$. Acetic anhydride $(0.13 \mathrm{~mL}, 1.36 \mathrm{mmol}, 4 \mathrm{eq})$ was added and the solution was stirred $20 \mathrm{~h}$ at room temperature and then concentrated under reduced pressure. The residue was purified using silica gel chromatography (10:1 hexanes:EtOAc) to yield $\mathbf{9}$ as an orange powder $(0.34 \mathrm{~g}, 31 \%$ from 4$)$. ${ }^{1} \mathrm{HNMR}\left(\mathrm{CDCl}_{3}, 600 \mathrm{MHz}\right) \delta 7.84(\mathrm{~s}, 1 \mathrm{H}), 5.36(\mathrm{~s}, 2 \mathrm{H}), 3.07(\mathrm{~s}, 6 \mathrm{H}), 2.16(\mathrm{~s}, 3 \mathrm{H})$.

${ }_{13} \mathrm{C}\{1 \mathrm{H}\} \mathrm{NMR}\left(\mathrm{CDCl}_{3}, 150 \mathrm{MHz}\right) \delta 171.0,154.7,152.4,143.5,133.7,131.7,108.6,62.3,44.8(2 \mathrm{C}), 21.2$. HRMS (ESI-TOF) m/z: [M+H]+ Calcd. for $\mathrm{C}_{11} \mathrm{H}_{13} \mathrm{BrN}_{3} \mathrm{O}_{2} \mathrm{~S} 329.9906$, found 329.9906 . 
<smiles>CCOCc1cc(Br)c2nsnc2c1N(C)CC(=O)N(C)Br</smiles>

Synthesis of 9: 7 (24 mg, $0.08 \mathrm{mmol}, 1 \mathrm{eq})$ and bromoethane $(0.06 \mathrm{~mL}, 0.8 \mathrm{mmol}, 10 \mathrm{eq})$ were dissolved in dry DMF (2 mL) and let stir for 5 minutes at rt. Sodium hydride $(19 \mathrm{mg}, 0.8 \mathrm{mmol}, 10 \mathrm{eq})$ was added and reacted overnight. The solution was diluted with $\mathrm{DCM}$ and partitioned with $\mathrm{NaOH}(2 \mathrm{M})$. Organic layer was dried with $\mathrm{Na}_{2} \mathrm{SO}_{4}$, concentrated under reduced pressure, and purified via column chromatography (1:4 ethyl acetate: hexanes) to yield (9) as an orange yellow solid (18 mg, 70\%). Purity was confirmed by UPLC (Figure S27).

${ }_{1}^{1} \mathrm{H} \mathrm{NMR}\left(\mathrm{CDCl}_{3}, 400 \mathrm{MHz}\right) \delta 7.97(\mathrm{~s}, 1 \mathrm{H}), 4.71(\mathrm{~s}, 2 \mathrm{H}), 3.60(\mathrm{q}, 7 \mathrm{MHz}, 2 \mathrm{H}), 3.06(\mathrm{~s}, 6 \mathrm{H}), 1.29(\mathrm{t}, 7 \mathrm{MHz}$, $3 \mathrm{H})$

${ }^{13} \mathrm{C}\{1 \mathrm{H}\} \operatorname{NMR}(100 \mathrm{MHz}, \mathrm{MeOD}) \delta 155.5,153.6,143.6,135.9,135.0,109.0,68.8,67.3,44.9(2 \mathrm{C}), 15.5$. HRMS (ESI-TOF) m/z: [M+H] + Calcd. for $\mathrm{C}_{11} \mathrm{H}_{15} \mathrm{BrN}_{3} \mathrm{OS} 316.0114$, found 316.0127<smiles>CC(=O)OCc1cc(Br)c2nsnc2c1N(C)C</smiles><smiles>CC(=O)OCc1ccc2nsnc2c1N(C)C</smiles>

Synthesis of 10: Based on a previously published procedure, 8 ( $0.05 \mathrm{~g}, 0.15 \mathrm{mmol}, 1 \mathrm{eq})$ and KOAc $(0.05 \mathrm{~g}, 0.5 \mathrm{mmol}, 3.3 \mathrm{eq})$ were dissolved in $\mathrm{EtOH}(3.8 \mathrm{~mL})$ and EtOAc $(1.3 \mathrm{~mL})$. The flask was purged with nitrogen before the addition of $10 \%$ palladium on carbon $(0.02 \mathrm{~g}, 0.15 \mathrm{mmol}, 1 \mathrm{eq})$. Hydrogen gas was bubbled through the reaction, and the solution was stirred at room temperature overnight under a balloon of $\mathrm{H}_{2}$. Upon completion of the reaction, the solution was filtered, partitioned between DCM and water, and the organic layer was dried over $\mathrm{Na}_{2} \mathrm{SO}_{4}$. The volatiles were removed under reduced pressure to yield 11 as an orange yellow solid $(0.01 \mathrm{~g}, 36 \%)$.

${ }^{1} \mathrm{H} \mathrm{NMR}\left(\mathrm{CDCl}_{3}, 400 \mathrm{MHz}\right) \delta 7.74(\mathrm{~d}, 9 \mathrm{MHz}, 1 \mathrm{H}), 7.60(\mathrm{~d}, 9 \mathrm{MHz}, 1 \mathrm{H}), 5.40(\mathrm{~s}, 2 \mathrm{H}), 3.08(\mathrm{~s}, 6 \mathrm{H}), 2.14(\mathrm{~s}$, $3 \mathrm{H})$

${ }^{13} \mathrm{C}\{1 \mathrm{H}\} \mathrm{NMR}\left(100 \mathrm{MHz}, \mathrm{CDCl}_{3}\right) \delta 171.0,156.5,152.7,143.9,131.4,130.8,117.2,62.7,44.8,21.1$. HRMS (ESI-TOF) m/z: [M+H]+ Calcd. for $\mathrm{C}_{11} \mathrm{H}_{13} \mathrm{~N}_{3} \mathrm{O}_{2} \mathrm{~S} 252.0801$, found 252.0811 

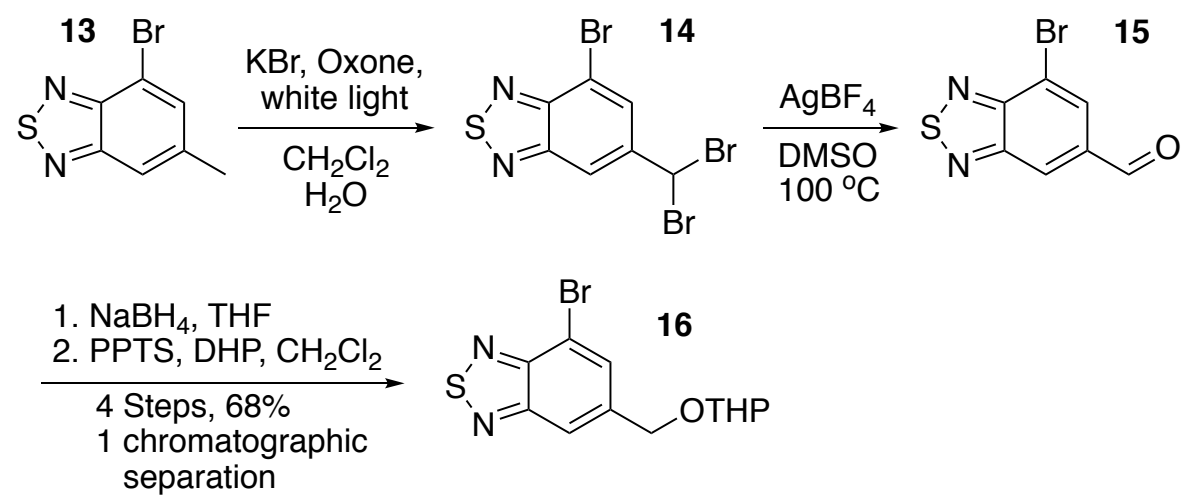

Bromination (13 $\rightarrow$ 14): Based on a previously published procedure, $313(1.5 \mathrm{~g}, 6.6 \mathrm{mmol}, 1 \mathrm{eq}$.$) ,$ potassium bromide (1.96g, $16.5 \mathrm{mmol}, 2.5 \mathrm{eq}$.$) , and Oxone (5.07 \mathrm{~g}, 16.5 \mathrm{mmol}, 2.5 \mathrm{eq}$.) were dissolved in a mixture of DCM $(48 \mathrm{~mL})$ and water $(6 \mathrm{~mL})$ in a round bottom flask. The flask was sealed and the mixture was emulsified with rapid stirring. The flask was irradiated with a white-light source (Luzchem LEDi-RGB head, $3200 \mathrm{~W} / \mathrm{m}^{2}$ ) under constant stirring. After $6 \mathrm{~h}$ the mixture was partitioned between DCM and water. The organic layer was collected, dried over $\mathrm{Na}_{2} \mathrm{SO}_{4}$, and concentrated under reduced pressure to yield a tan solid as a mixture of 2:1 di- and mono-brominated product (Please see crude ${ }^{1} \mathrm{H}$ NMR, Figure S9). The product was used without further purification.

Kornblum oxidation (14 $\rightarrow$ 15): Based on a previously published procedure, ${ }^{4}$ the mixture of brominated benzothiadiazoles $(\mathbf{1 4}, 2.0 \mathrm{~g}, 6.5 \mathrm{mmol}, 1 \mathrm{eq}$.) was dissolved in DMSO $(10 \mathrm{~mL})$. Silver tetrafluoroborate $\left(2.5 \mathrm{~g}, 13 \mathrm{mmol}, 2 \mathrm{eq}\right.$.) was added. The mixture was heated with stirring at $100{ }^{\circ} \mathrm{C}$ in an oil bath for $6 \mathrm{~h}$. The mixture was filtered through $20 \mu \mathrm{m}$ PTFE filter and partitioned between DCM and water. The organic layer was washed with water (3x), dried over $\mathrm{Na}_{2} \mathrm{SO}_{4}$, and concentrated under reduced pressure to yield a tan solid (Please see crude ${ }^{1} \mathrm{H}$ NMR, Figure S10). The product was used without further purification.

Reduction and Protection (15 $\rightarrow$ 16): 15 (1.31 g, 5.4 mmol, 1 eq.) and $\mathrm{NaBH}_{4}(0.611 \mathrm{~g}, 16.2 \mathrm{mmol}, 3$ eq) was dissolved in THF (53 mL). The solution was stirred for $12 \mathrm{~h}$ and was partitioned between DCM and water. The organic layer was dried over $\mathrm{Na}_{2} \mathrm{SO}_{4}$ and concentrated under reduced pressure. The residue was dissolved into DCM $(41 \mathrm{~mL})$. 3,4-dihydro-2H-pyran (1.1 mL, $12.5 \mathrm{mmol}, 2.3$ eq.) and PPTS (105 mg, $0.42 \mathrm{mmol}, .08 \mathrm{eq}$.) were added and the reaction was stirred overnight. The reaction was diluted with $\mathrm{DCM}$ and washed with water and brine. The organic layer was dried over $\mathrm{Na}_{2} \mathrm{SO}_{4}$ and concentrated under reduced pressure. The residue was purified by column chromatography ( $4: 1$ / hexane:EtOAc) to yield 17 as an orange yellow powder ( $1.37 \mathrm{~g}, 68 \%$ yield over 4 steps).

${ }_{1} \mathrm{H} \mathrm{NMR}\left(\mathrm{CDCl}_{3}, 400 \mathrm{MHz}\right) \delta 7.91(\mathrm{~d}, J=1 \mathrm{MHz}, 1 \mathrm{H}), 7.83(\mathrm{~d}, J=1 \mathrm{MHz}, 1 \mathrm{H}), 4.92(\mathrm{dd}, J=13.2,1 \mathrm{MHz}$, $1 \mathrm{H}), 4.76(\mathrm{t}, J=3.5 \mathrm{MHz}, 1 \mathrm{H}), 4.64(\mathrm{dd}, J=13.2,1 \mathrm{MHz}, 1 \mathrm{H}), 3.90(\mathrm{~m}, 1 \mathrm{H}), 3.58(\mathrm{~m}, 1 \mathrm{H}), 1.72(\mathrm{~m}, 6 \mathrm{H})$. ${ }^{13} \mathrm{C}\{1 \mathrm{H}\} \operatorname{NMR}\left(100 \mathrm{MHz}, \mathrm{CDCl}_{3}\right) \delta 155.1,153.4,142.0,132.5,118.8,114.6,98.7,68.0,62.7,30.9,25.8$, 19.7.

HRMS (ESI-TOF) m/z: [M+Na]+ Calcd. for $\mathrm{C}_{12} \mathrm{H}_{13} \mathrm{BrN}_{2} \mathrm{O}_{2} \mathrm{SNa} 350.9773$, found 350.2299

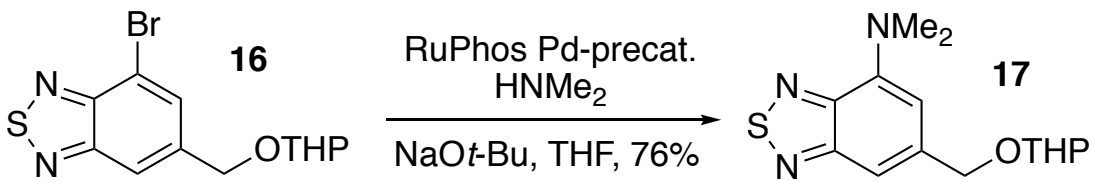

Synthesis of 17: Based on a previously reported procedure, ${ }^{5}$ RuPhos Pd-precatalyst [CAS 1445085-777] (25.9 mg, $0.031 \mathrm{mmol}, 0.1$ eq.), RuPhos ligand [CAS 787618-22-8] (14.5 mg, $0.031 \mathrm{mmol}, 0.1 \mathrm{eq}$.), and $t$-BuONa (59.6 mg, $0.62 \mathrm{mmol}, 2$ eq.) were added to a flamed dried Schlenk tube was added under nitrogen. 17 (104.2 mg, $0.31 \mathrm{mmol}$, 1 eq.) was dissolved in THF ( $3 \mathrm{~mL})$ and degassed by sonication under vacuum. The THF solution was then added through a septum to the solids in the flask along with 2 
$\mathrm{M}$ dimethyl amine in THF $(0.31 \mathrm{~mL}, 0.62 \mathrm{mmol}, 2$ eq. $)$. The reaction was stirred at $50^{\circ} \mathrm{C}$ in an oil bath for $12 \mathrm{~h}$ and was partitioned between DCM and water. The organic layer was washed with water and brine, dried over $\mathrm{Na}_{2} \mathrm{SO}_{4}$ and concentrated under reduced pressure. The residue was purified via silica gel chromatography (9:1 hexanes:EtOAc) to give 17 as an orange yellow solid (65 mg, 76\%).

${ }^{1} \mathrm{H} \mathrm{NMR}\left(\mathrm{CDCl}_{3}, 400 \mathrm{MHz}\right) \delta 7.43(\mathrm{~d}, J=1 \mathrm{MHz}, 1 \mathrm{H}), 6.53(\mathrm{~s}, 1 \mathrm{H}), 4.87(\mathrm{dd}, J=13.1,1 \mathrm{MHz}, 1 \mathrm{H}), 4.77$ (t, $J=3.5 \mathrm{MHz}, 1 \mathrm{H}), 4.61(\mathrm{~d}, J=13.0,1 \mathrm{H}), 3.95(\mathrm{~m}, 1 \mathrm{H}), 3.57(\mathrm{~m}, 1 \mathrm{H}), 3.27(\mathrm{~s}, 6 \mathrm{H}), 1.72(\mathrm{~m}, 6 \mathrm{H})$.

${ }^{13} \mathrm{C}\{1 \mathrm{H}\} \operatorname{NMR}(100 \mathrm{MHz}, \mathrm{CDCl} 3) \delta 157.1,149.1,144.1,141.7,109.1,108.7,98.0,77.3,68.8,62.3,42.5$, 30.6, 25.5, 19.4 .

HRMS (ESI-TOF) m/z: [M+H]+ Calcd. for $\mathrm{C}_{14} \mathrm{H}_{20} \mathrm{~N}_{3} \mathrm{O}_{2} \mathrm{~S} 294.1271$, found 294.1307

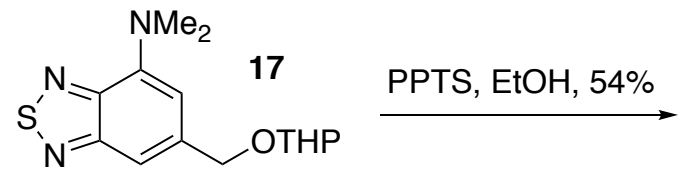<smiles>CN(C)c1cc(CO)cc2nsnc12</smiles>

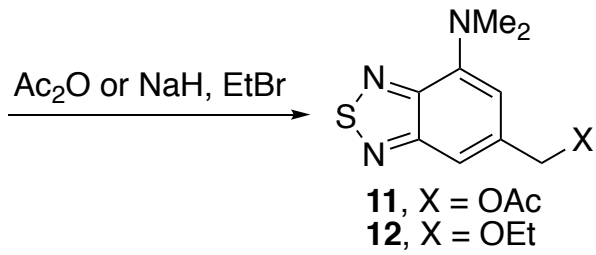

THP deprotection 18: 17 (66 mg, .22 mmol, $1 \mathrm{eq}$ ) and pyridinium $p$-toluenesulfonate (PPTS, $5.52 \mathrm{mg}$, $.022 \mathrm{mmol}, 1 \mathrm{eq}$ ) were dissolved in $1.5 \mathrm{~mL}$ of EtOH and stirred at $55{ }^{\circ} \mathrm{C}$ in an oil bath for $6 \mathrm{~h}$. The solution was concentrated under reduced pressure and the residue was purified via silica gel column chromatography (1:1 hexanes:EtOAc) to yield 18 as an orange yellow solid ( $25 \mathrm{mg}, 54 \%)$. ${ }_{1}^{1} \mathrm{H} \mathrm{NMR}\left(\mathrm{CDCl}_{3}, 400 \mathrm{MHz}\right) \delta 7.34(\mathrm{q}, J=1 \mathrm{MHz}, 1 \mathrm{H}), 6.52(\mathrm{~s}, 1 \mathrm{H}), 4.77(\mathrm{~d}, J=1 \mathrm{MHz}, 2 \mathrm{H}), 3.26(\mathrm{~s}, 6 \mathrm{H})$ ${ }_{13} \mathrm{C}\{1 \mathrm{H}\} \operatorname{NMR}(100 \mathrm{MHz}, \mathrm{CDCl} 3) \delta 157.0,149.0,144.2,144.1,108.0,108.0,65.4,42.5$.

HRMS (ESI-TOF) m/z: [M+H]+ Calcd. for $\mathrm{C}_{9} \mathrm{H}_{12} \mathrm{~N}_{3} \mathrm{OS} 210.0696$, found 210.0712

Synthesis of 11: The product of THP deprotection (18) from above (25 mg, $0.12 \mathrm{mmol}, 1 \mathrm{eq}$.), acetic anhydride (.045 mL, .48 mmol, 4 eq.), and pyridine $(0.077 \mathrm{~mL}, .96 \mathrm{mmol}, 8$ eq.) were dissolved in $0.6 \mathrm{~mL}$ of DCM and. The reaction was left to stir at it for $48 \mathrm{~h}$. The solution was concentrated under reduced pressure and the residue was purification by silica gel column chromatography (1:5 EtOAc:hexanes) to yield 11 as an orange yellow solid (22 $\mathrm{mg}, 73 \%$ yield).

${ }^{1} \mathrm{H} \mathrm{NMR}\left(\mathrm{CDCl}_{3}, 400 \mathrm{MHz}\right) \delta 7.38$ (bs, 1H), $6.44(\mathrm{~s}, 1 \mathrm{H}), 5.19(\mathrm{~s}, 2 \mathrm{H}), 3.29(\mathrm{~s}, 6 \mathrm{H}), 2.16(\mathrm{~s}, 3 \mathrm{H})$ ${ }^{13} \mathrm{C}\{1 \mathrm{H}\}$ NMR $\left(100 \mathrm{MHz}, \mathrm{CDCl}_{3}\right) \delta 170.8,156.9,149.0,144.2,139.1,109.4,108.1,66.3,42.5$ (2C), 21.0. HRMS (ESI-TOF) m/z: [M+H]+ Calcd. for $\mathrm{C}_{11} \mathrm{H}_{14} \mathrm{~N}_{3} \mathrm{O}_{2} \mathrm{~S} 252.0801$, found 252.0807

Synthesis of 12: The product of THP deprotection (18) from above ( $30 \mathrm{mg}, 0.14 \mathrm{mmol}, 1 \mathrm{eq}$ ) and bromoethane $(0.04 \mathrm{~mL}, 0.56 \mathrm{mmol}, 4 \mathrm{eq})$ were dissolved in dry DMF $(2 \mathrm{~mL})$. Sodium hydride $(13 \mathrm{mg}, 0.56$ $\mathrm{mmol}, 4 \mathrm{eq}$ ) was added and the reaction was stirred overnight. The mixture was diluted with DCM and partitioned with $\mathrm{NaOH}(2 \mathrm{M})$. The organic layer was dried with $\mathrm{Na}_{2} \mathrm{SO}_{4}$, concentrated under reduced pressure, and purified via column chromatography (1:4 ethyl acetate: hexanes) to yield $\mathbf{1 2}$ as an orangeyellow solid (13 mg, 40\%). Purity was confirmed by UPLC (Figure S28) ${ }_{1}^{1} \mathrm{H} \mathrm{NMR}\left(\mathrm{CDCl}_{3}, 400 \mathrm{MHz}\right) \delta 7.37(\mathrm{~s}, 1 \mathrm{H}), 6.55(\mathrm{~s}, 1 \mathrm{H}), 4.59(\mathrm{~s}, 2 \mathrm{H}), 3.59$ (q, $\left.7 \mathrm{MHz}, 2 \mathrm{H}\right), 3.27(\mathrm{~s}, 6 \mathrm{H})$, $1.28(\mathrm{t}, 7 \mathrm{Mhz}, 3 \mathrm{H})$ ${ }^{13} \mathrm{C}\{1 \mathrm{H}\} \mathrm{NMR}\left(100 \mathrm{MHz}, \mathrm{CDCl}_{3}\right) \delta 157.2,149.3,144.3,142.0,109.3,108.8,72.9,66.1,42.7(2 \mathrm{C}), 15.4$. HRMS (ESI-TOF) m/z: [M+H]+ Calcd. for $\mathrm{C}_{11} \mathrm{H}_{16} \mathrm{~N}_{3} \mathrm{OS} 238.1009$, found 238.1022 

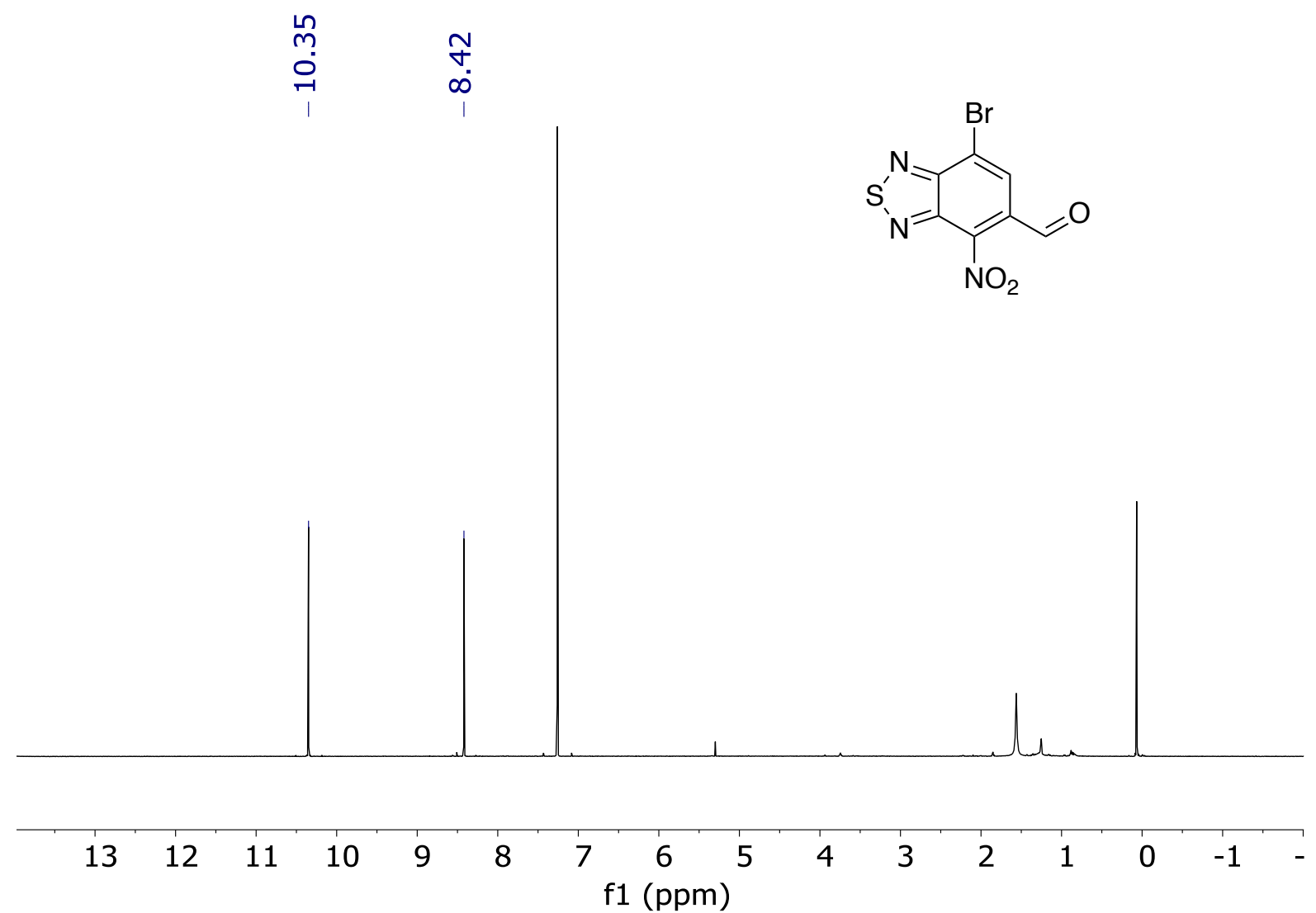

Figure S1. ${ }^{1} \mathrm{H}$ NMR spectrum of $4\left(\mathrm{CDCl}_{3}, 600 \mathrm{MHz}\right)$.
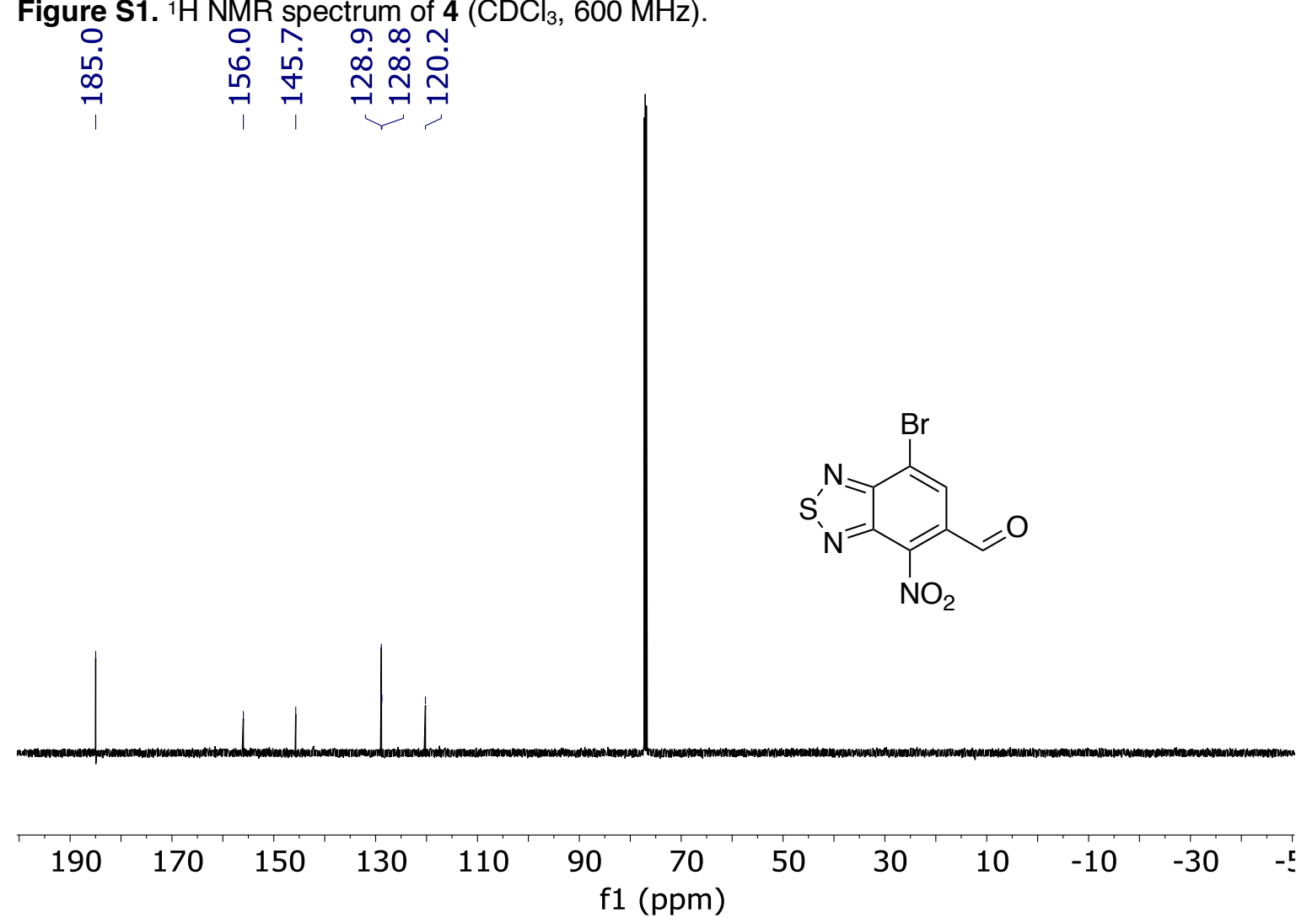

Figure $52 .{ }^{13} \mathrm{C}\{1 \mathrm{H}\}$ NMR spectrum of $4\left(\mathrm{CDCl}_{3}, 150 \mathrm{MHz}\right)$ 


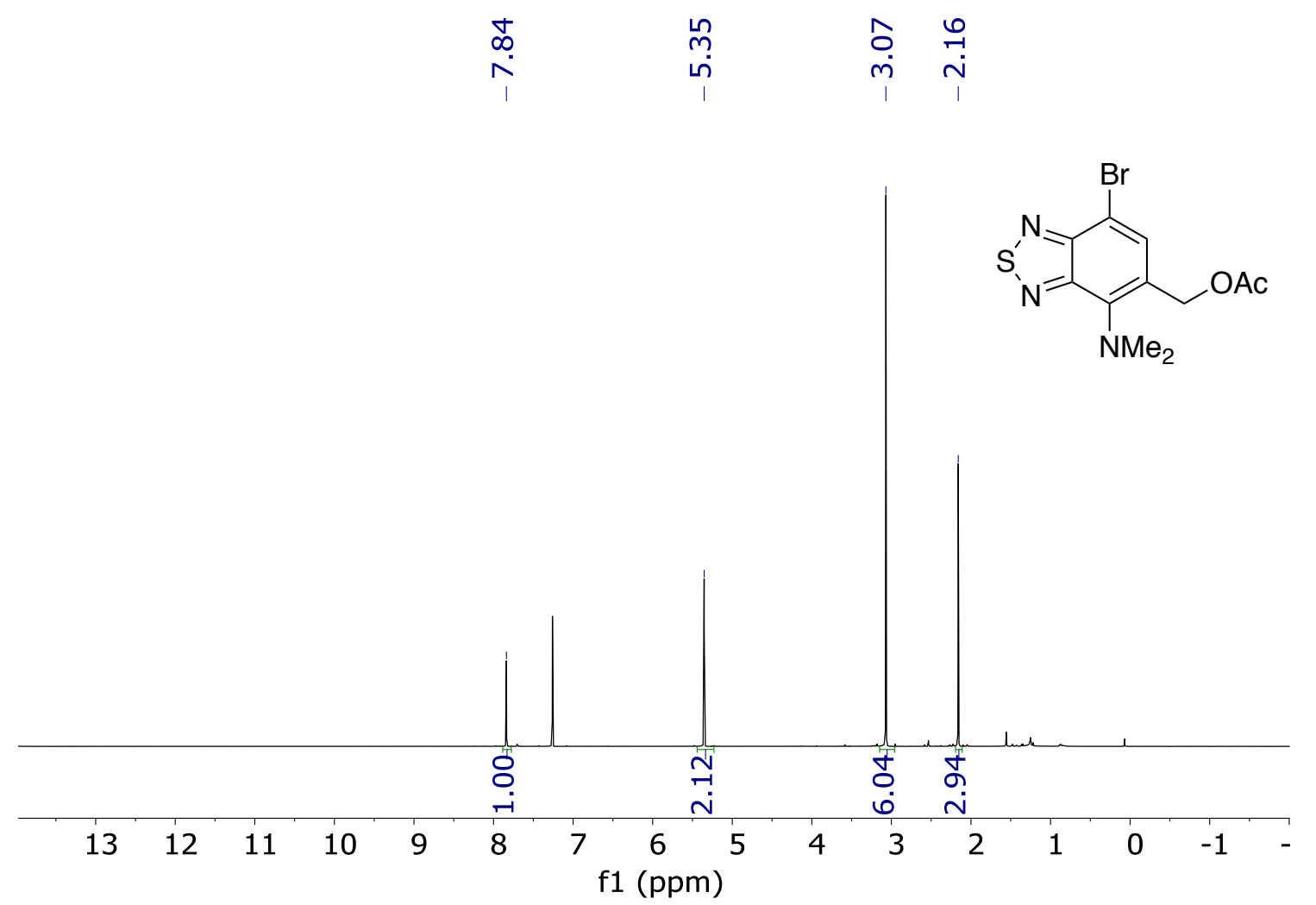

Figure S3. ${ }^{1 \mathrm{H}} \mathrm{NMR}$ spectrum of $8\left(\mathrm{CDCl}_{3}, 400 \mathrm{MHz}\right)$.



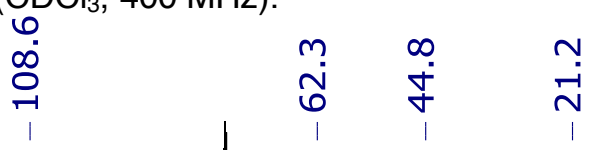<smiles>CC(=O)OCc1cc(Br)c2nsnc2c1N(C)C</smiles>

$\begin{array}{lllllllllllll}190 & 170 & 150 & 130 & 110 & 90 & \begin{array}{c}70 \\ \mathrm{f} 1(\mathrm{ppm})\end{array} & 50 & 30 & 10 & -10 & -30 & -5\end{array}$

Figure S4. ${ }^{13} \mathrm{C}\{1 \mathrm{H}\} \quad \mathrm{NMR}$ spectrum of $8\left(\mathrm{CDCl}_{3}, 150 \mathrm{MHz}\right)$ 


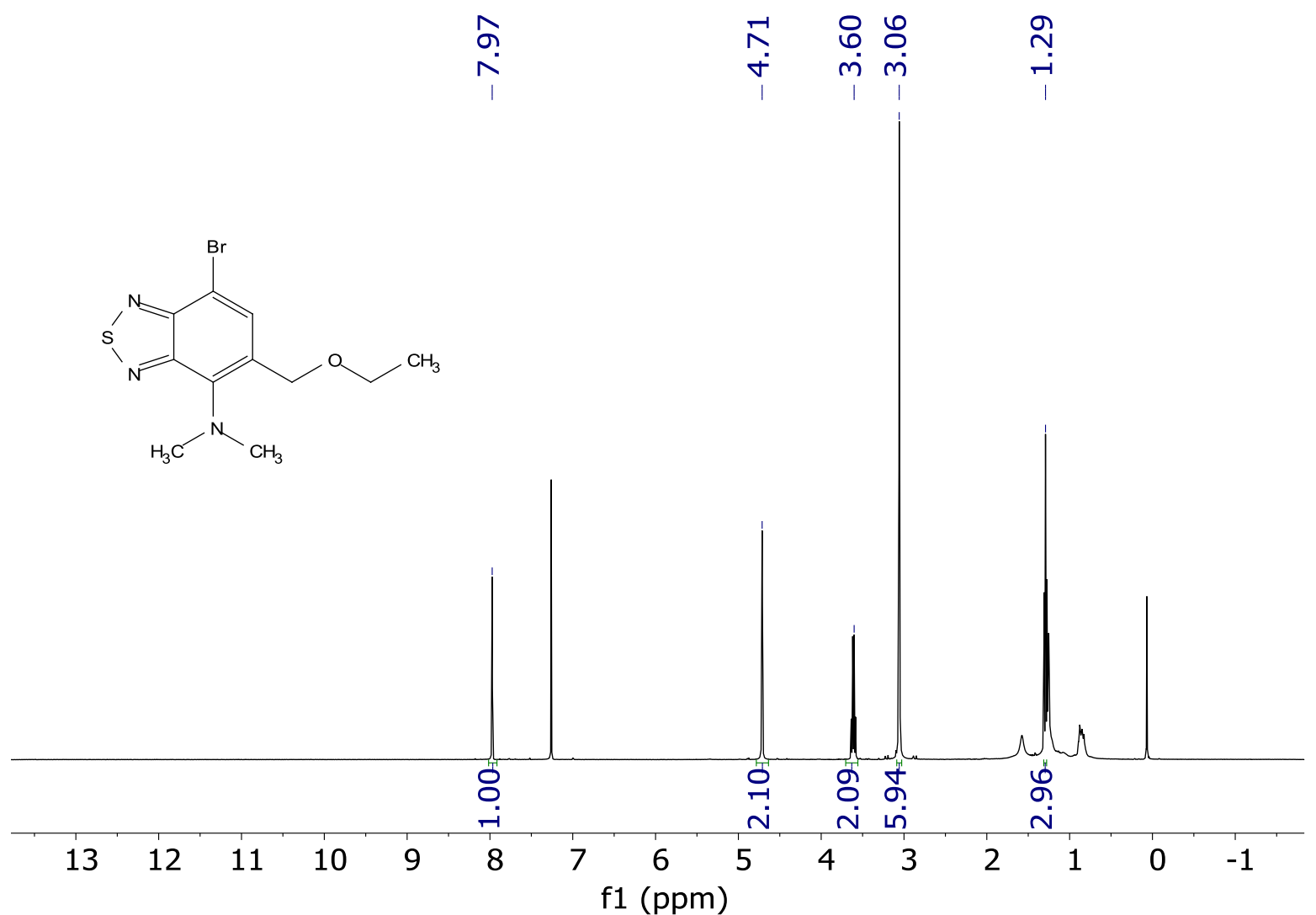

Figure S5. ${ }^{1} \mathrm{H}$ NMR spectrum of $9\left(\mathrm{CDCl}_{3}, 400 \mathrm{MHz}\right)$. Purity was confirmed by UPLC (Figure S27).
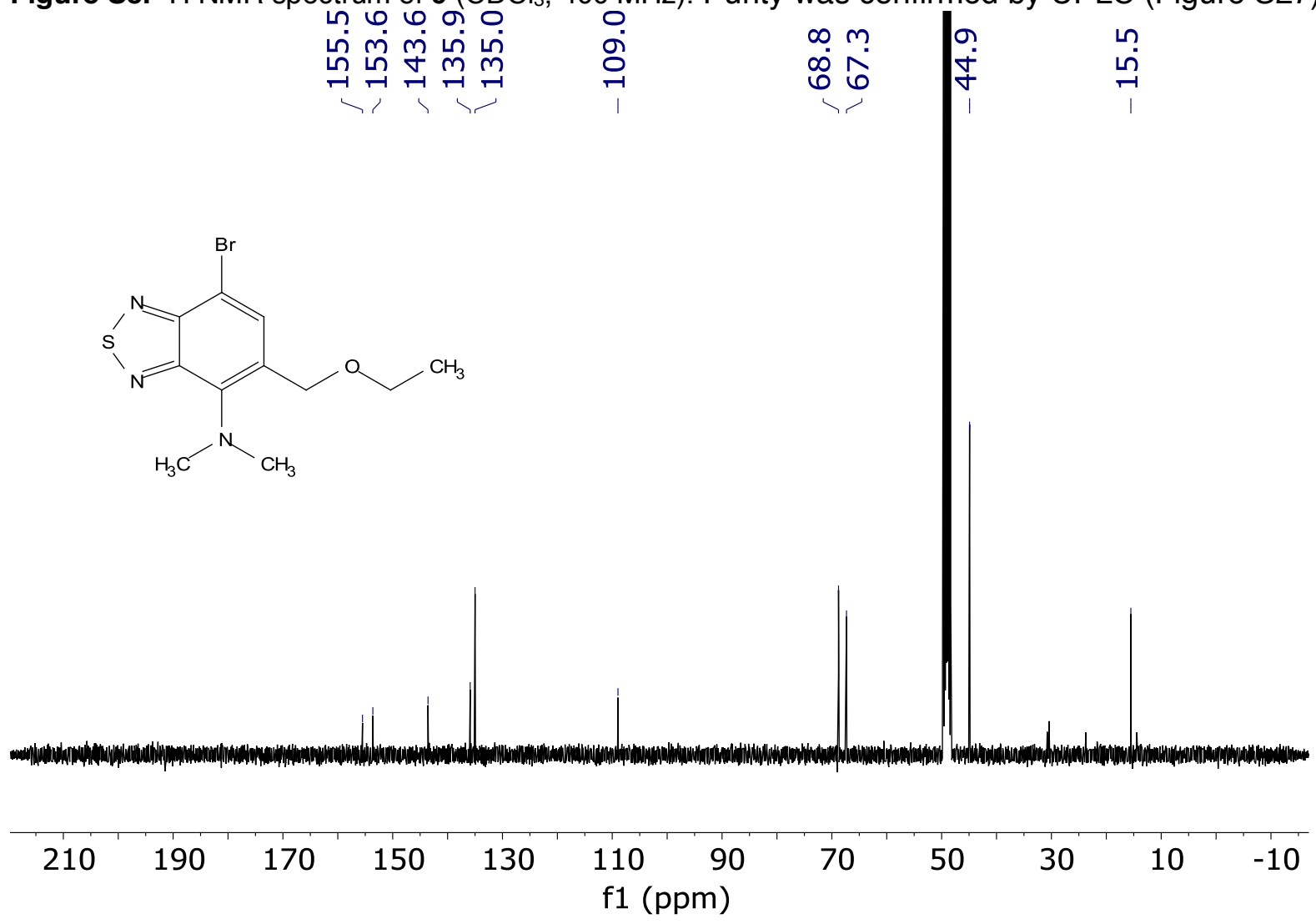

Figure S6. ${ }^{13} \mathrm{C}\{1 \mathrm{H}\}$ NMR spectrum of $9\left(\mathrm{CD}_{3} \mathrm{OD}, 100 \mathrm{MHz}\right)$ 


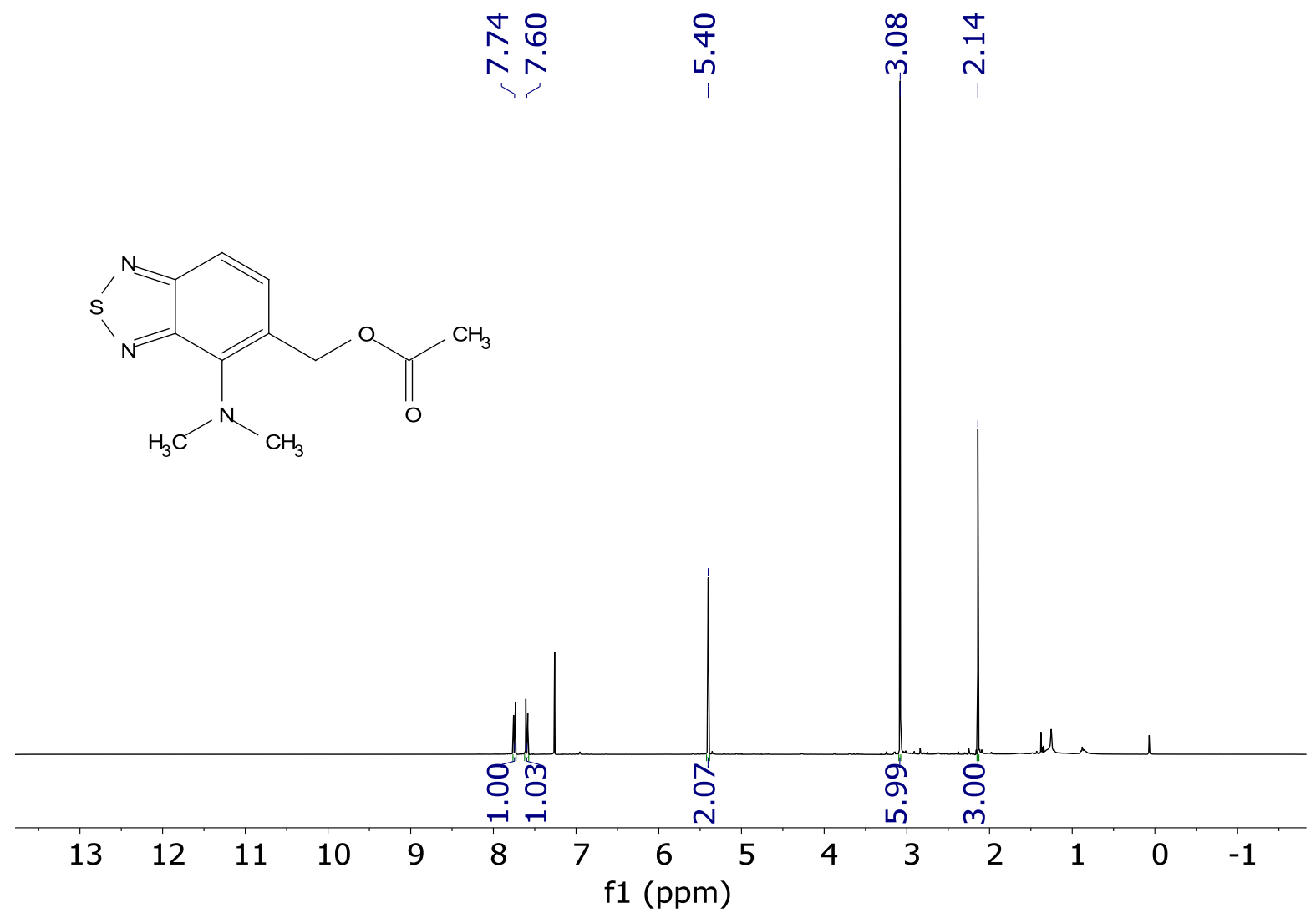

Figure S7. ${ }^{1} \mathrm{H}$ NMR spectrum of $10\left(\mathrm{CDCl}_{3}, 400 \mathrm{MHz}\right)$.


\begin{tabular}{lllllllllll}
\hline 210 & 190 & 170 & 150 & 130 & $\begin{array}{c}110 \\
\mathrm{f} 1(\mathrm{ppm})\end{array}$ & $\begin{array}{c}90 \\
(100\end{array}$ & 50 & 30 & 10 & -10
\end{tabular}

Figure S8. ${ }^{13} \mathrm{C}\{1 \mathrm{H}\}$ NMR spectrum of $10\left(\mathrm{CDCl}_{3}, 100 \mathrm{MHz}\right)$ 

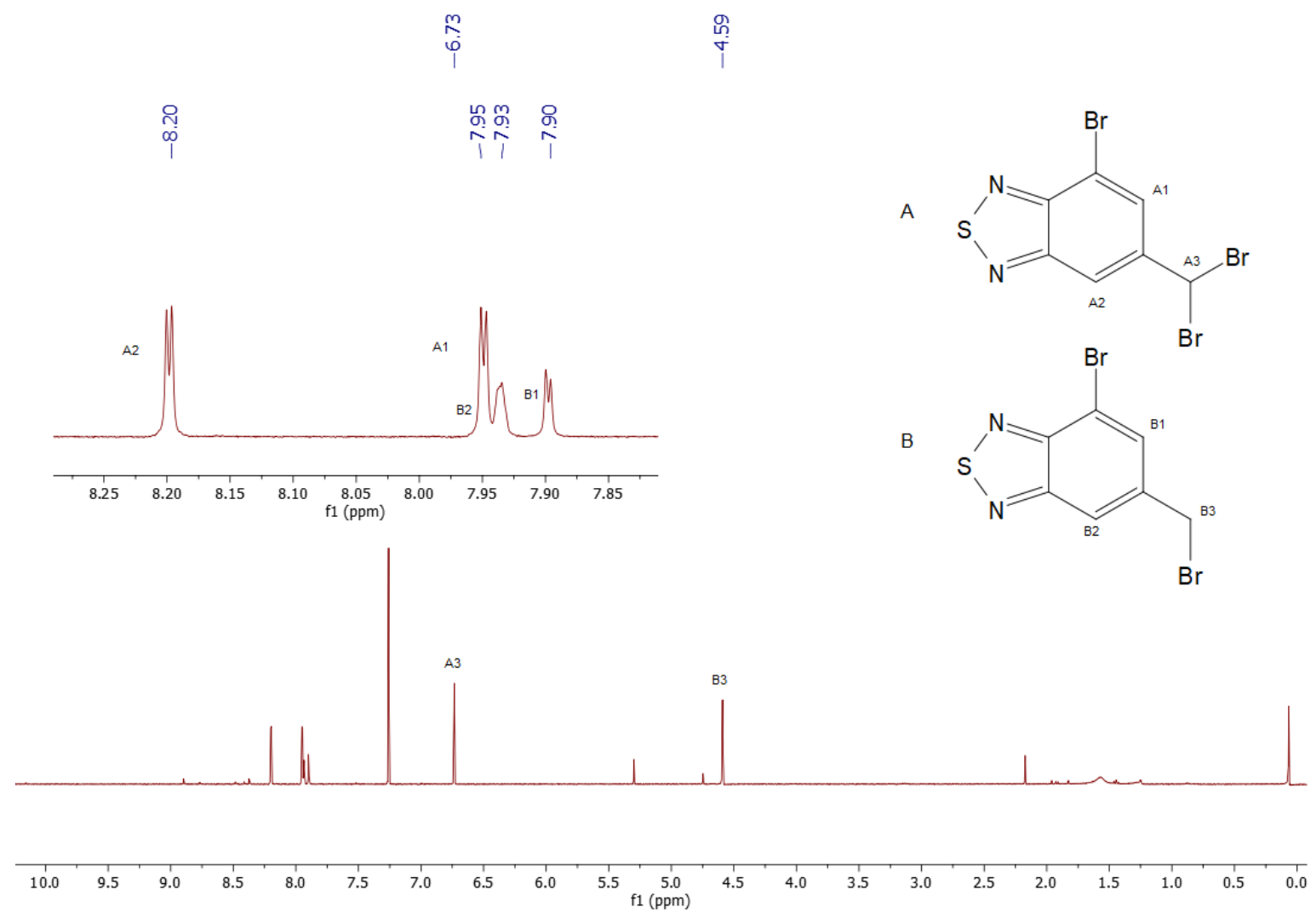

Figure S9. Crude ${ }^{1} \mathrm{H}$ NMR spectrum of $14\left(\mathrm{CDCl}_{3}, 400 \mathrm{MHz}\right)$.
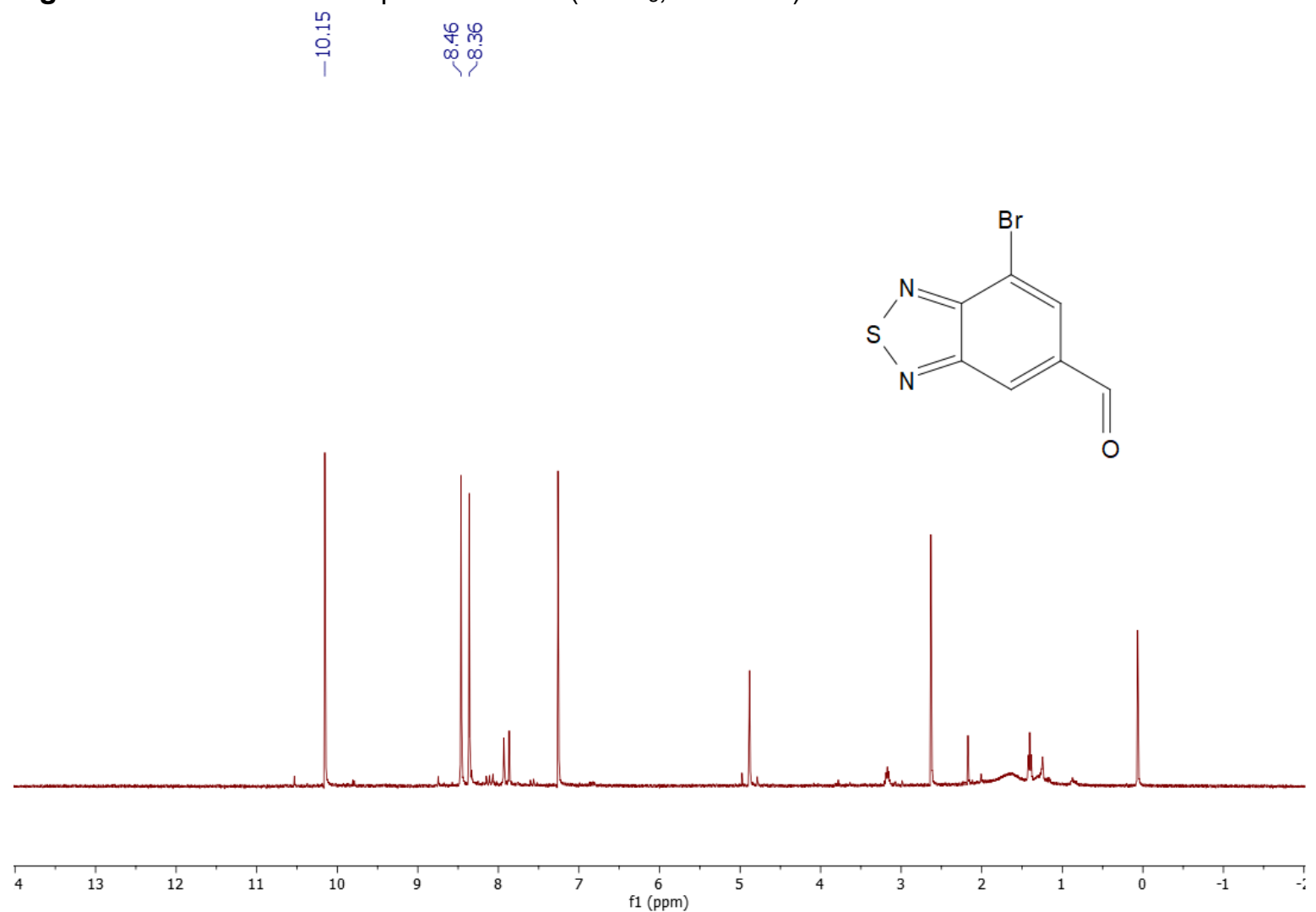

Figure S10. Crude ${ }^{1} \mathrm{H}$ NMR spectrum of $15\left(\mathrm{CDCl}_{3}, 400 \mathrm{MHz}\right)$. 


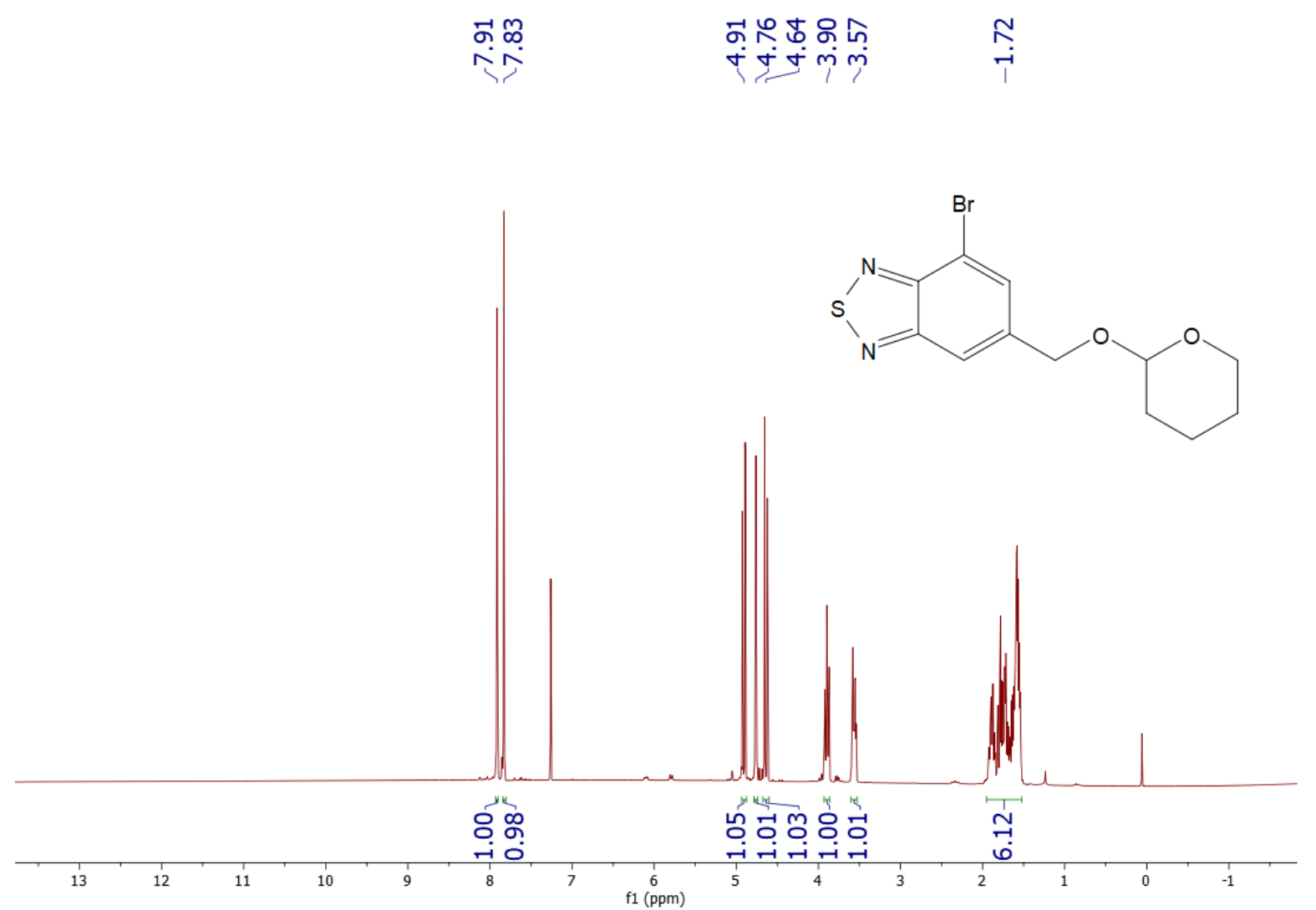

Figure S11. ${ }^{1 \mathrm{H}} \mathrm{NMR}$ spectrum of $16\left(\mathrm{CDCl}_{3}, 400 \mathrm{MHz}\right)$.

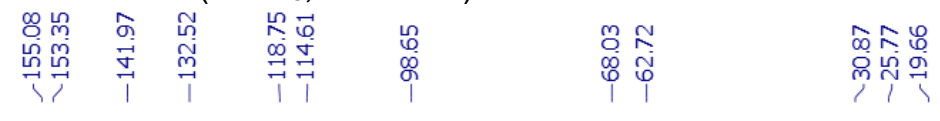<smiles>Brc1cc(COC2CCCCO2)cc2nsnc12</smiles>
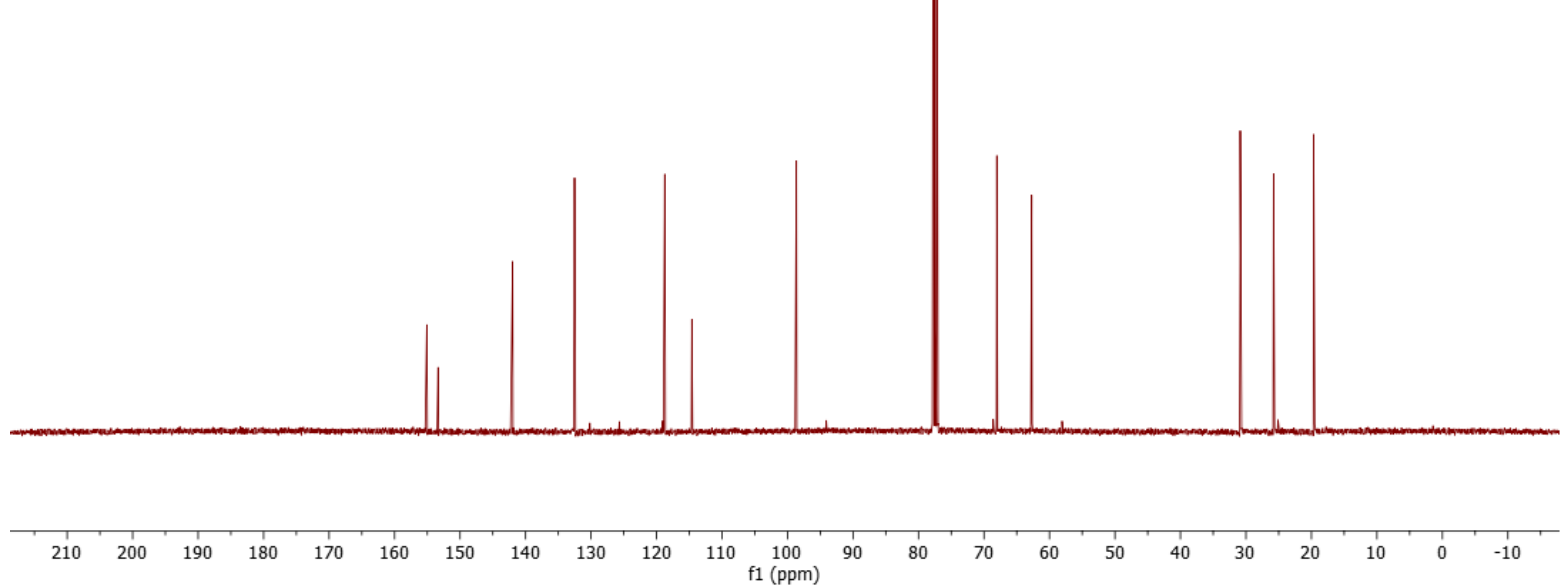

Figure $\mathrm{S} 12 .{ }^{13} \mathrm{C}\{1 \mathrm{H}\}$ NMR spectrum of $16\left(\mathrm{CDCl}_{3}, 100 \mathrm{MHz}\right)$ 


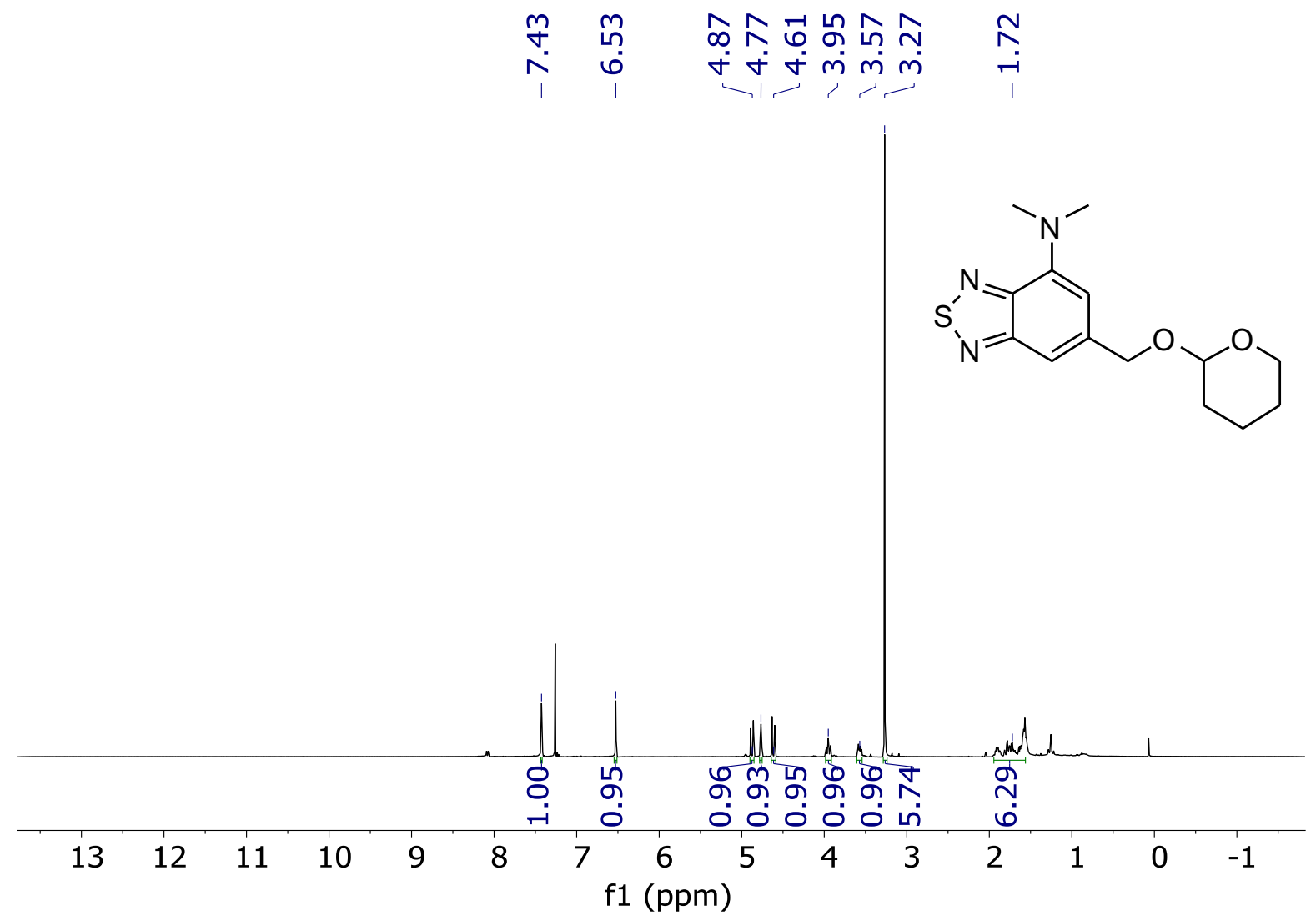

Figure S13. ${ }^{1 \mathrm{H}} \mathrm{NMR}$ spectrum of $17\left(\mathrm{CDCl}_{3}, 400 \mathrm{MHz}\right)$.

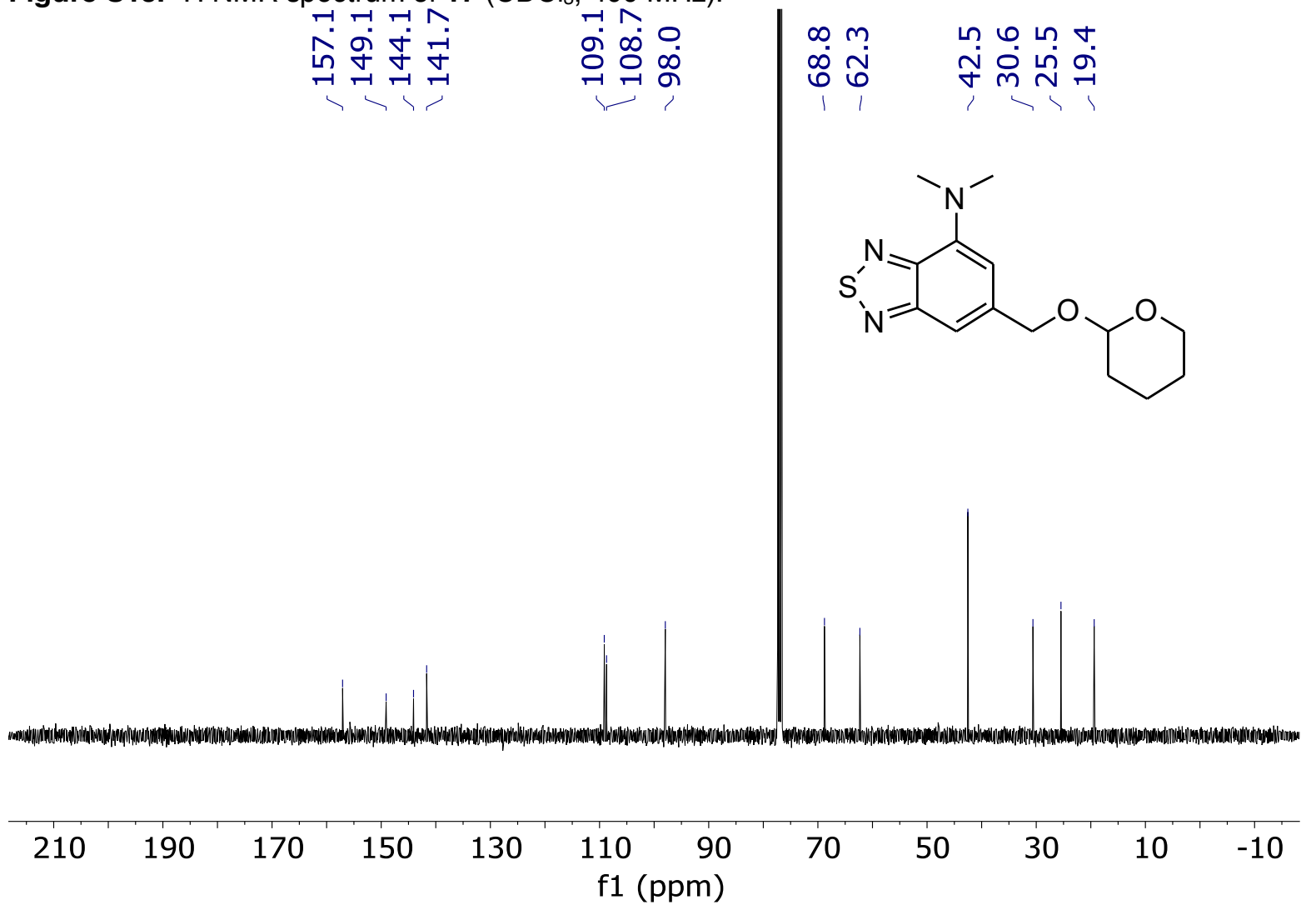

Figure $\mathrm{S} 14 .{ }^{13} \mathrm{C}\{1 \mathrm{H}\} \mathrm{NMR}$ spectrum of $17\left(\mathrm{CDCl}_{3}, 100 \mathrm{MHz}\right)$ 


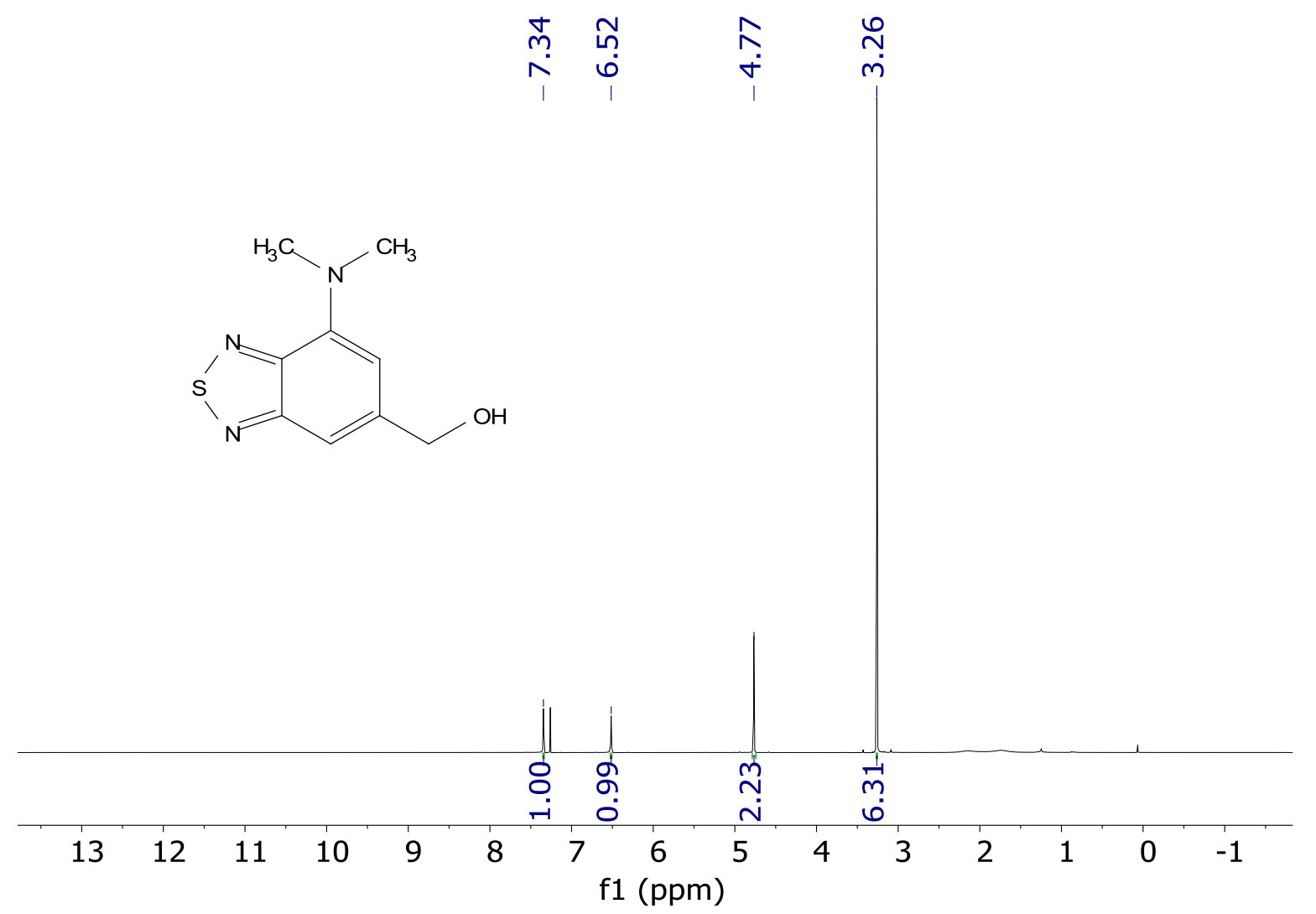

Figure S15. ${ }^{1} \mathrm{H}$ NMR spectrum of $18\left(\mathrm{CDCl}_{3}, 400 \mathrm{MHz}\right)$.

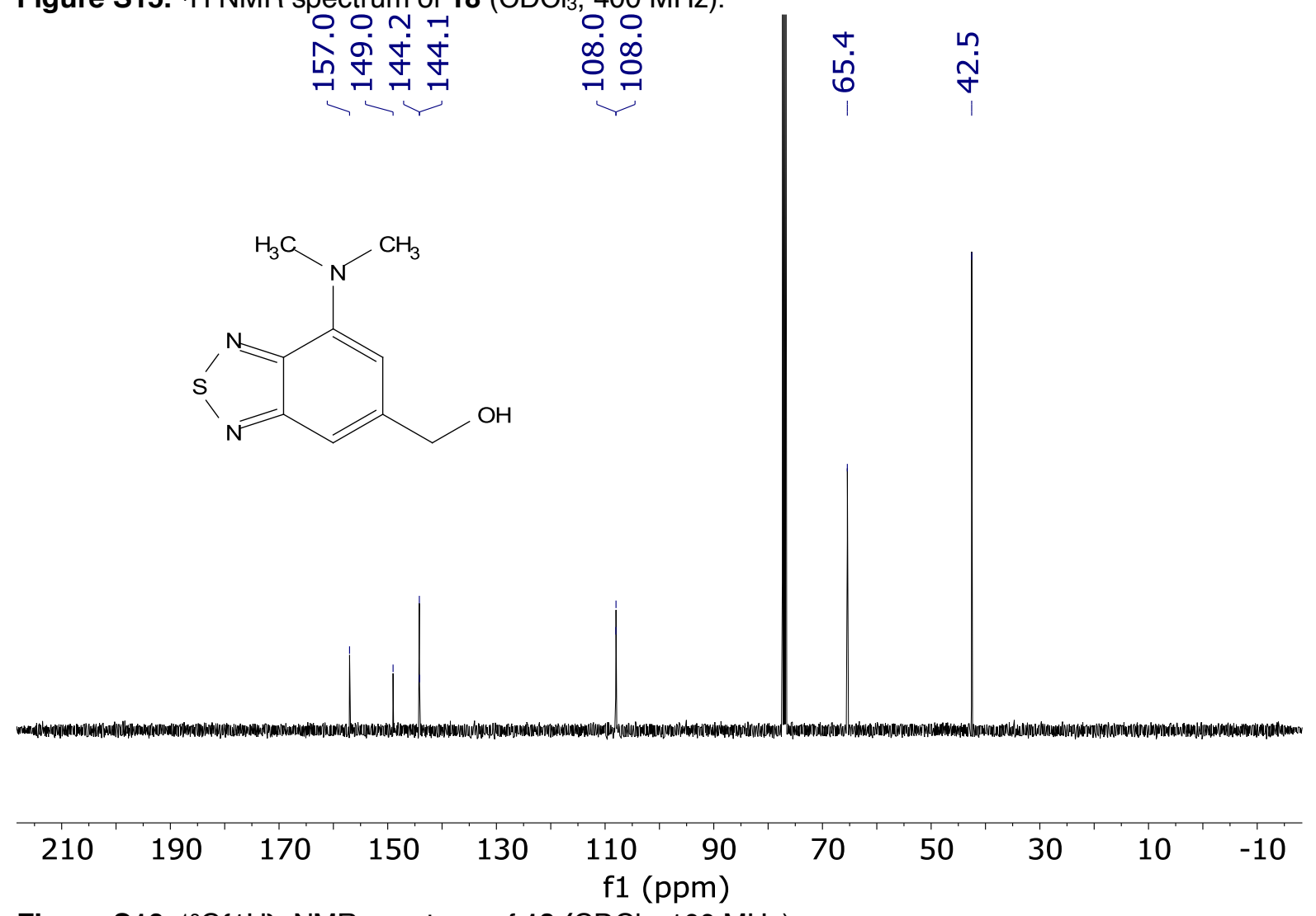

Figure $\mathrm{S} 16 .{ }^{13} \mathrm{C}\{1 \mathrm{H}\} \mathrm{NMR}$ spectrum of $18\left(\mathrm{CDCl}_{3}, 100 \mathrm{MHz}\right)$ 


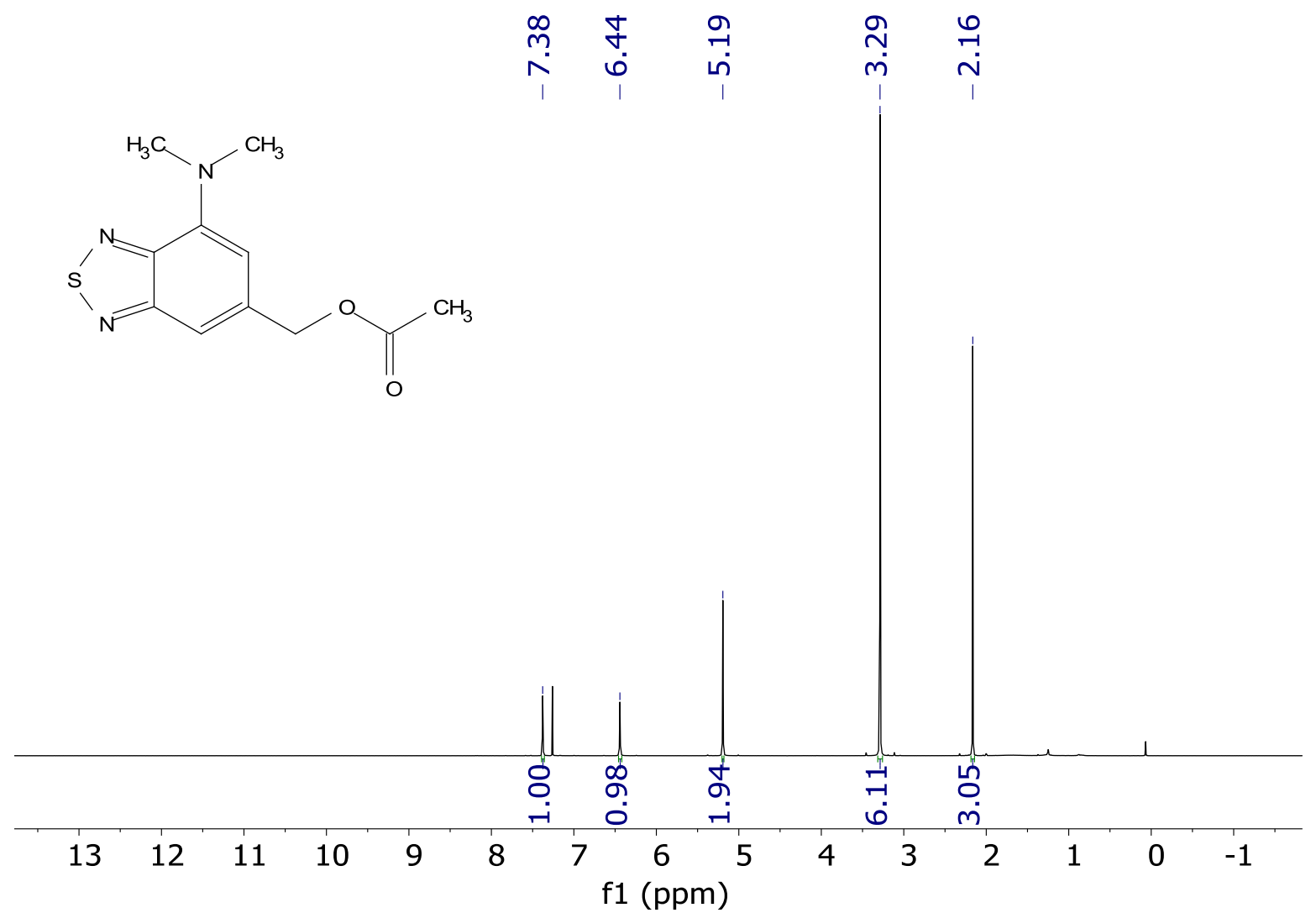

Figure S17. ${ }^{1} \mathrm{H}$ NMR spectrum of $11\left(\mathrm{CDCl}_{3}, 400 \mathrm{MHz}\right)$.

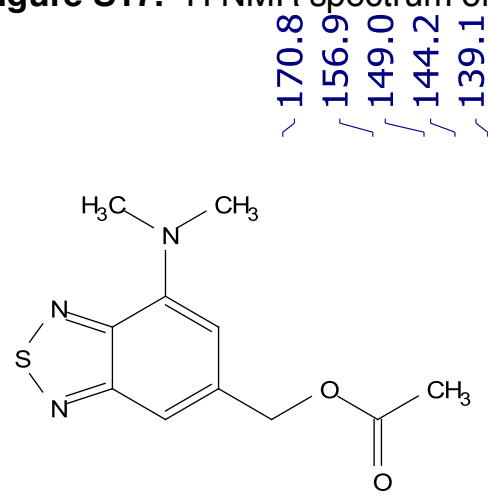

\begin{tabular}{|c|c|c|c|c|c|c|c|c|c|c|c|}
\hline 210 & 190 & 170 & 150 & 130 & $\begin{array}{r}110 \\
\mathrm{f} 1\end{array}$ & $\begin{array}{r}90 \\
\mathrm{pm})\end{array}$ & 70 & 50 & 30 & 10 & -10 \\
\hline
\end{tabular}

Figure $\mathrm{S} 18 .{ }^{13} \mathrm{C}\{1 \mathrm{H}\} \mathrm{NMR}$ spectrum of $11\left(\mathrm{CDCl}_{3}, 100 \mathrm{MHz}\right)$ 


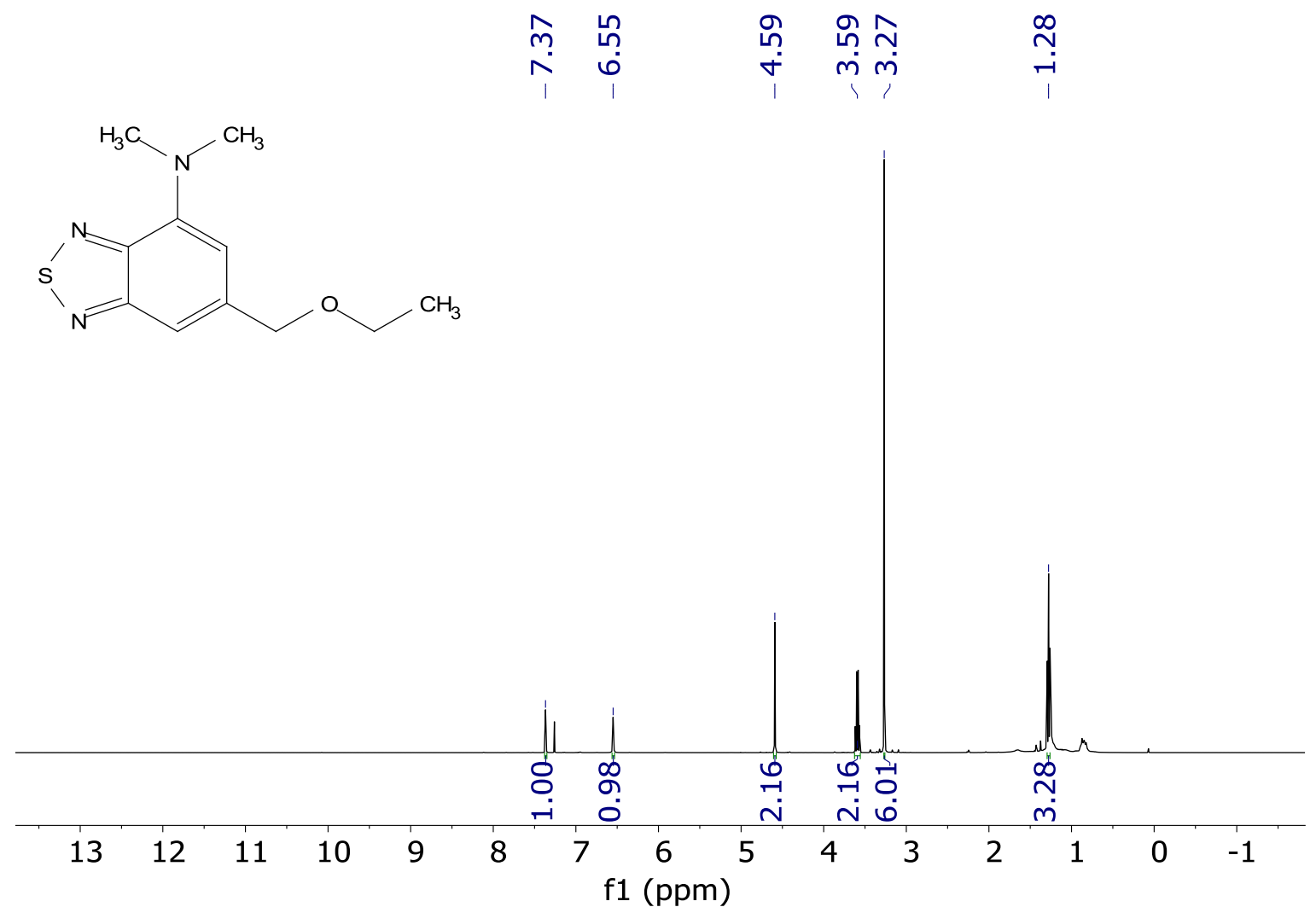

Figure S19. ${ }^{1} \mathrm{H}$ NMR spectrum of $12\left(\mathrm{CDCl}_{3}, 400 \mathrm{MHz}\right)$. Purity was confirmed by UPLC (Figure S28)
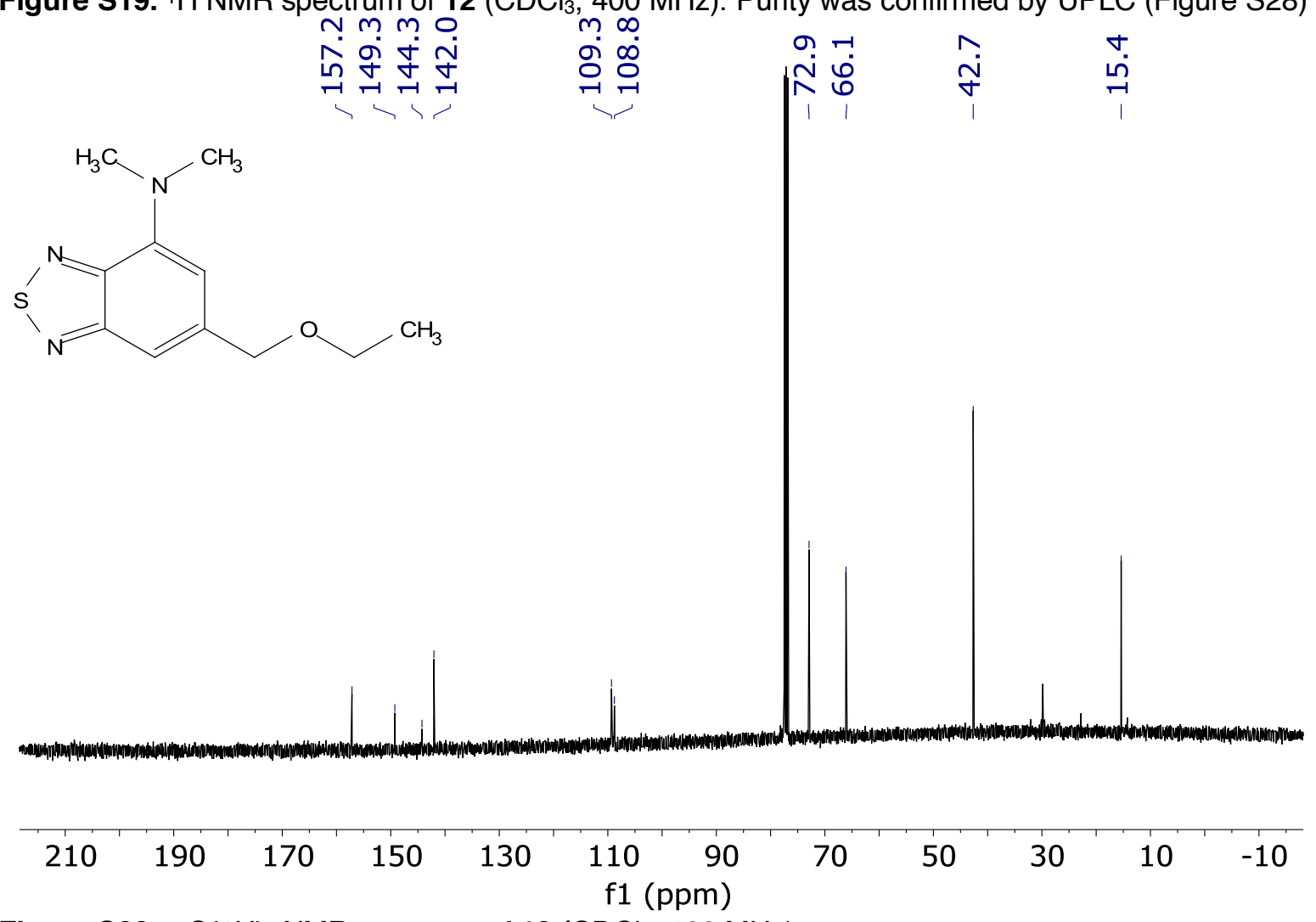

Figure S20. ${ }^{13} \mathrm{C}\{1 \mathrm{H}\}$ NMR spectrum of $12\left(\mathrm{CDCl}_{3}, 100 \mathrm{MHz}\right)$ 


\section{Quantum Yield Determinations}

Irradiations were performed using a Luzchem ${ }^{\circledR}$ LED Illuminator $(455 \mathrm{~nm})$ photoreactor. Determination of the quantum yield of 8-12 was performed by tracking the extent of photocleavage of leaving group by NMR relative to the BODIPY standard shown at right.

We first determined the quantum yield of release of acetate from the BODIPY standard at $455 \mathrm{~nm}$ using a potassium ferrioxalate actinometer.

Fresh aqueous solutions of potassium ferrioxalate trihydrate were prepared following previously reported procedures. ${ }^{6}$ All manipulation of reagents and reaction solutions were performed in a dark room under far red light illumination to reduce background

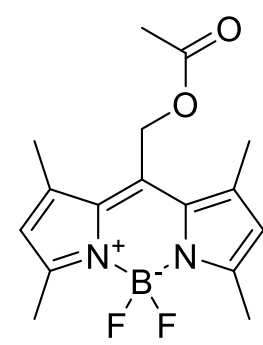

BODIPY standard photochemistry.

Solutions of potassium ferrioxalate were irradiated at $455 \mathrm{~nm}$ (in a standard $10 \mathrm{~mm}$ cuvette) for the time durations listed on the $x$-axis of the graph below. Irradiation lead to the photoreduction of $\mathrm{Fe}$ (III) to $\mathrm{Fe}$ (II) with an established quantum yield for this process of 0.89 .

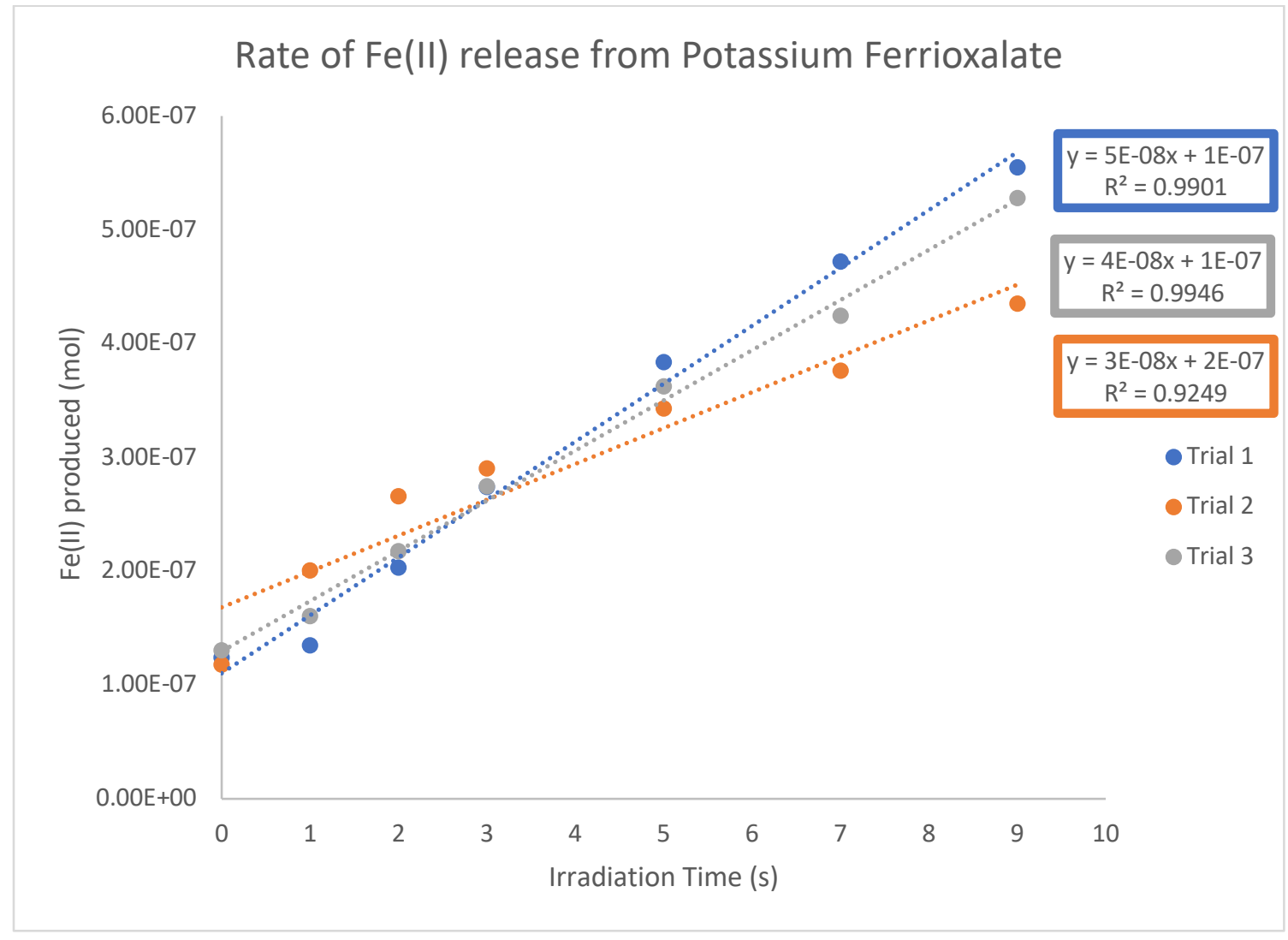

The concentration of reduced $\mathrm{Fe}$ (II) in the potassium ferrioxalate solution was determined by complexation with 1,10-phenanthroline as described previously. ${ }^{6}$ The UV-vis absorbance of the $\mathrm{Fe}$ (II)phenanthroline complex at $510 \mathrm{~nm}$ was monitored and quantified relative to a standard calibration curve created from known concentrations of $\mathrm{Fe}(\mathrm{II})$ sulfate and phenanthroline.

Solutions of BODIPY in $\mathrm{CDCl}_{3}$ were then irradiated at $455 \mathrm{~nm}$ (in a standard $10 \mathrm{~mm}$ cuvette) for the time durations listed on the $\mathrm{x}$-axis of the graph below. Irradiation lead to the release of acetic acid which was 
determined by removing aliquots from the cuvette and analyzing by ${ }^{1} \mathrm{H}$ NMR for the extent of acetic acid produced relative to ethylene carbonate as an internal standard.

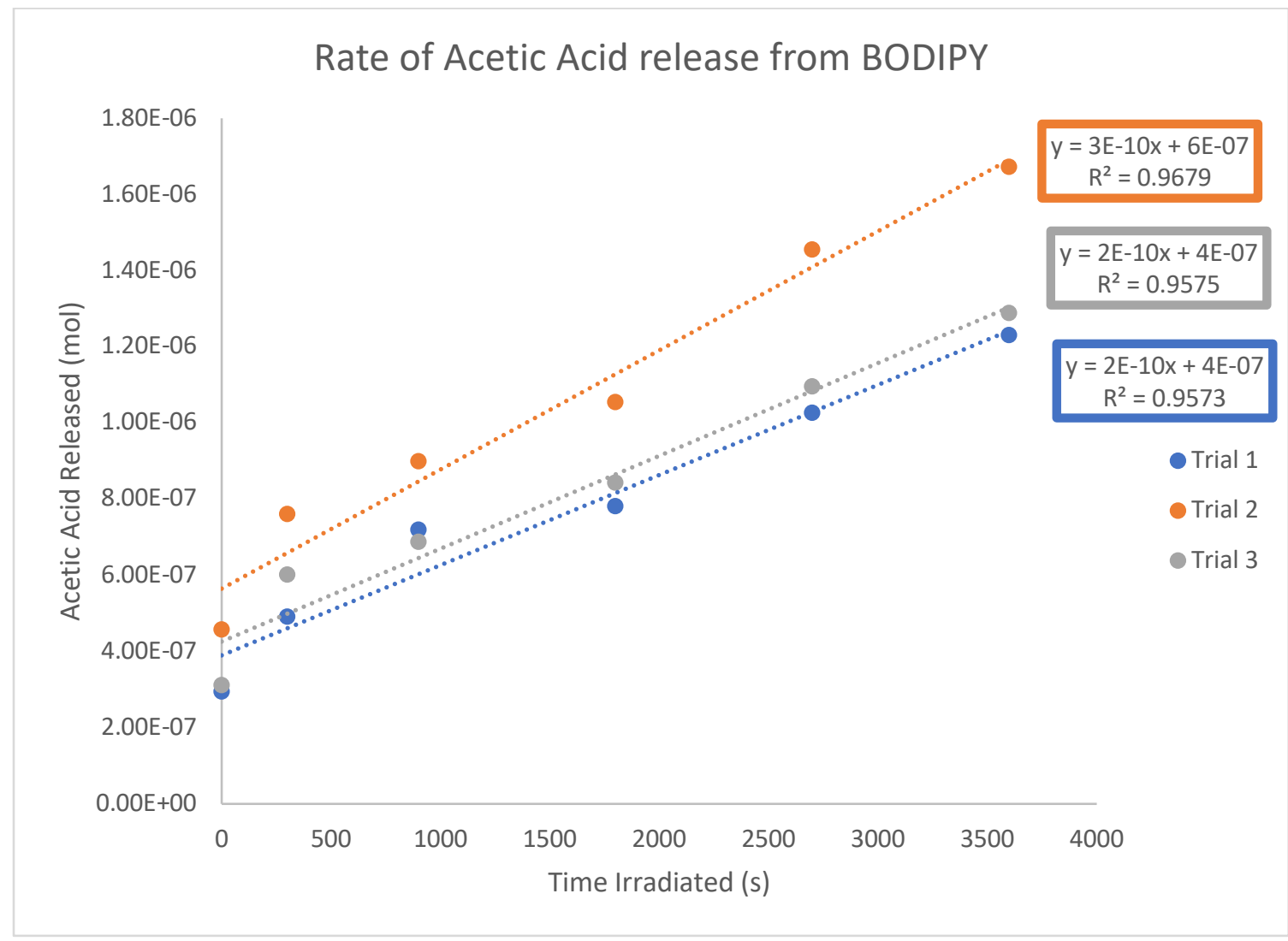

The quantum yield of release of acetic acid from BODIPY at $455 \mathrm{~nm}$ in $\mathrm{CDCl}_{3}$ was determined using the equation below, where $r$ is the rate of reaction from the respective graphs above. The rate was calculated based on the first $10 \%$ of the reaction to ensure linearity of the rate.

$$
\Phi_{B O D I P Y}=\frac{r_{B O D I P Y}}{r_{F e(I I)}} \Phi_{\text {ferrioxalate }}
$$

We determined a quantum yield of acetic acid release from BODIPY of 0.00597 , which agrees with literature values. ${ }^{7}$ BODIPY was then used as an actinometer with a more convenient NMR read-out. ${ }^{8}$

Solutions of 8-12 with unknown quantum yields of release were prepared in $\mathrm{CD}_{3} \mathrm{OD}$ in a $10 \mathrm{~mm}$ cuvette with an absorbance $>4$ au at $455 \mathrm{~nm}$ as determined by a Agilent Technologies Cary 8454 UV-Vis Diode Array System. These solutions were transferred to NMR tubes (inner diameter $4.14 \mathrm{~mm}$ ) such that the final absorbance of the solution in the NMR tube was halved to $>2$ au (Absorbance of 2 au ensures $>99 \%$ of incident light is absorbed by the sample). This same procedure was performed for BODIPY in $\mathrm{CDCl}_{3}$. All solutions were prepared with ethylene carbonate as internal standard.

The rates of the release of leaving group from BODIPY and 8-12 relative to internal standard under photolysis at $455 \mathrm{~nm}$ was then determined using ${ }^{1} \mathrm{H}$ NMR. The quantum yield of release of leaving groups from 8-12 was determined using the equation below, where $r$ is the rate of reaction from the respective 
table below as determined by NMR. The rate was calculated based on the first $10 \%$ of the reaction to ensure linearity of the rate.

$$
\Phi_{\text {unknown }}=\frac{r_{\text {unknown }}}{r_{B O D I P Y \text { release }}} * \Phi_{B O D I P Y}
$$

The data below was used for the calculation of the quantum yield.

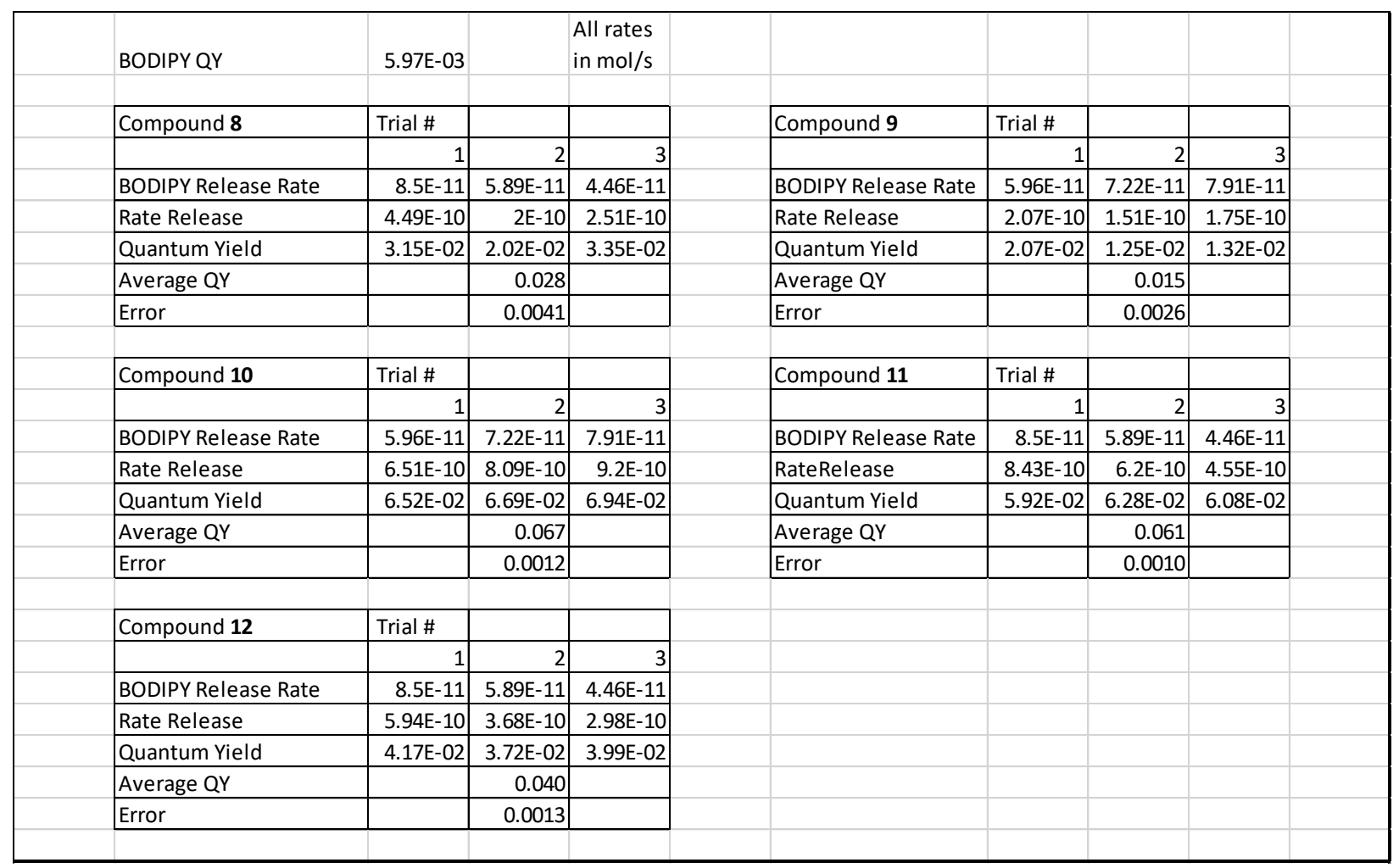




\section{Representative Irradiation Trials}
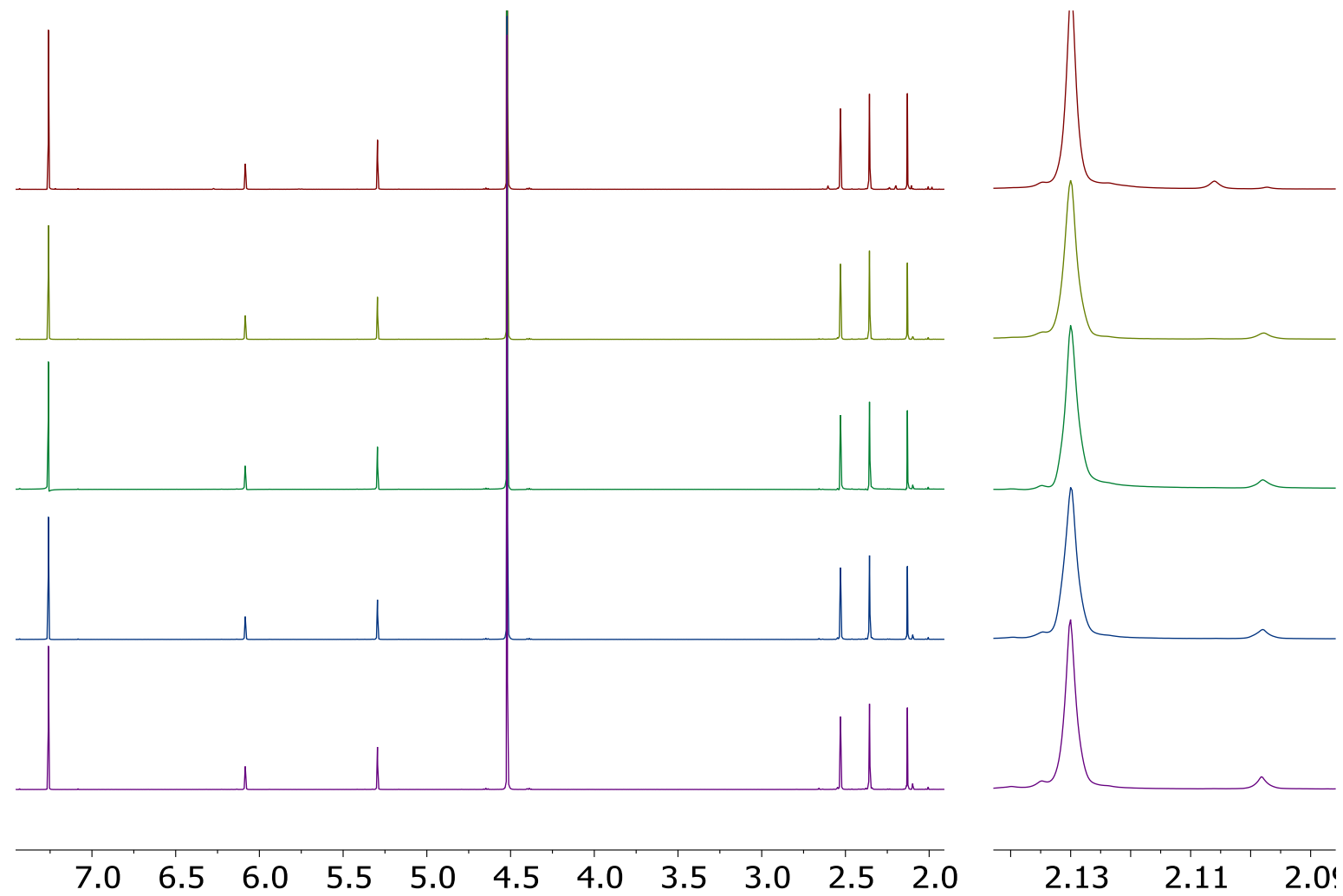

f1 (ppm)

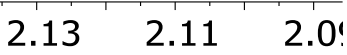

f1 (ppm)

Figure S21: Representative ${ }^{1} \mathrm{H}$ NMR of irradiated BODIPY. Top trace is time $=0$. Increments of 15 min descending. Zoom of leaving group on right. 


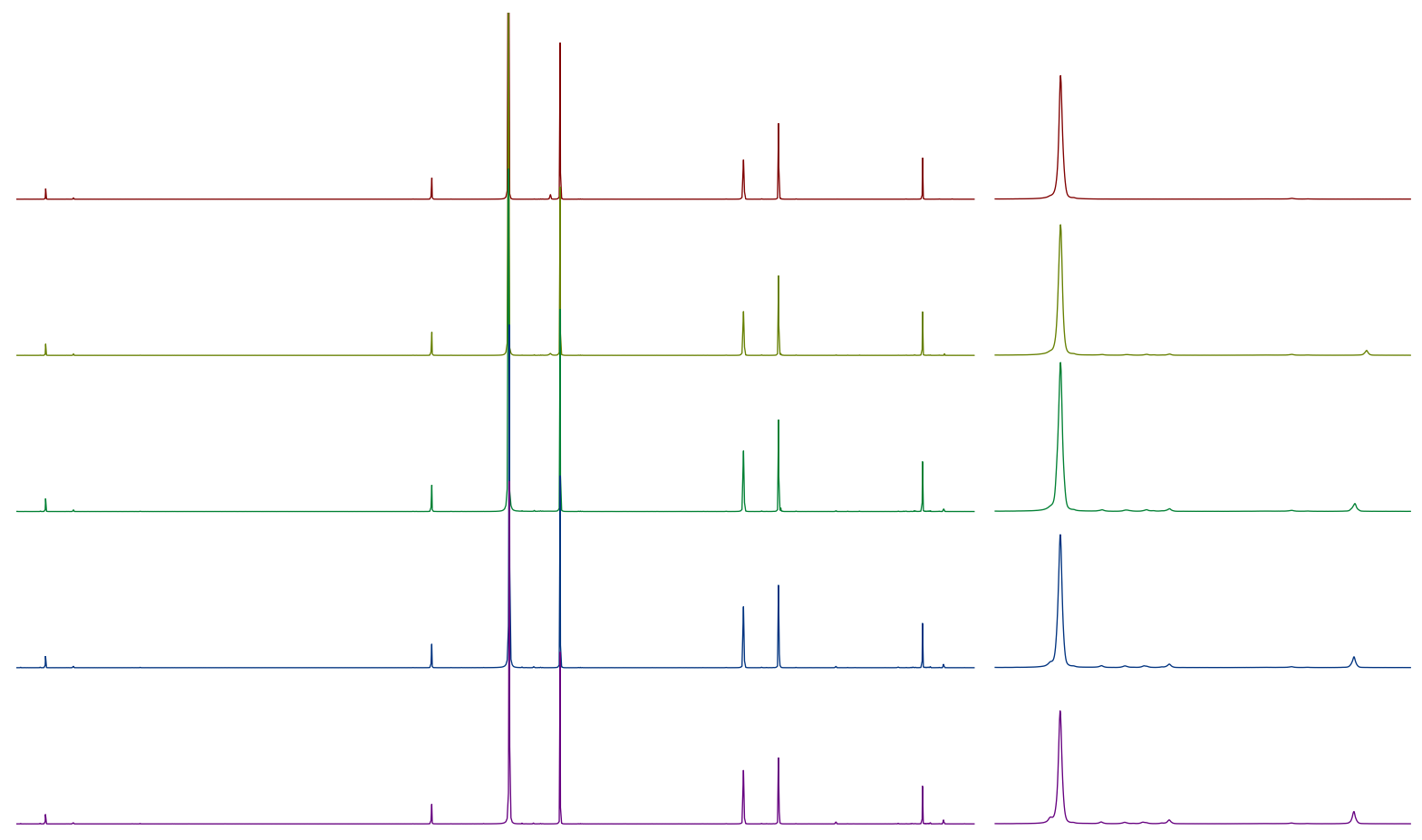

\begin{tabular}{llllllllllllllllll}
\hline 8.0 & 7.5 & 7.0 & 6.5 & 6.0 & 5.5 & 5.0 & 4.5 & 4.0 & 3.5 & 3.0 & 2.5 & 2.0 & 2.15 & 2.10 & 2.05 & 2.00
\end{tabular} f1 (ppm)

f1 (ppm)

Figure S22: Representative ${ }^{1} \mathrm{H}$ NMR of irradiated 8. Top trace is time $=0$. Increments of $5 \mathrm{~min}$ descending. Zoom of leaving group on right. 


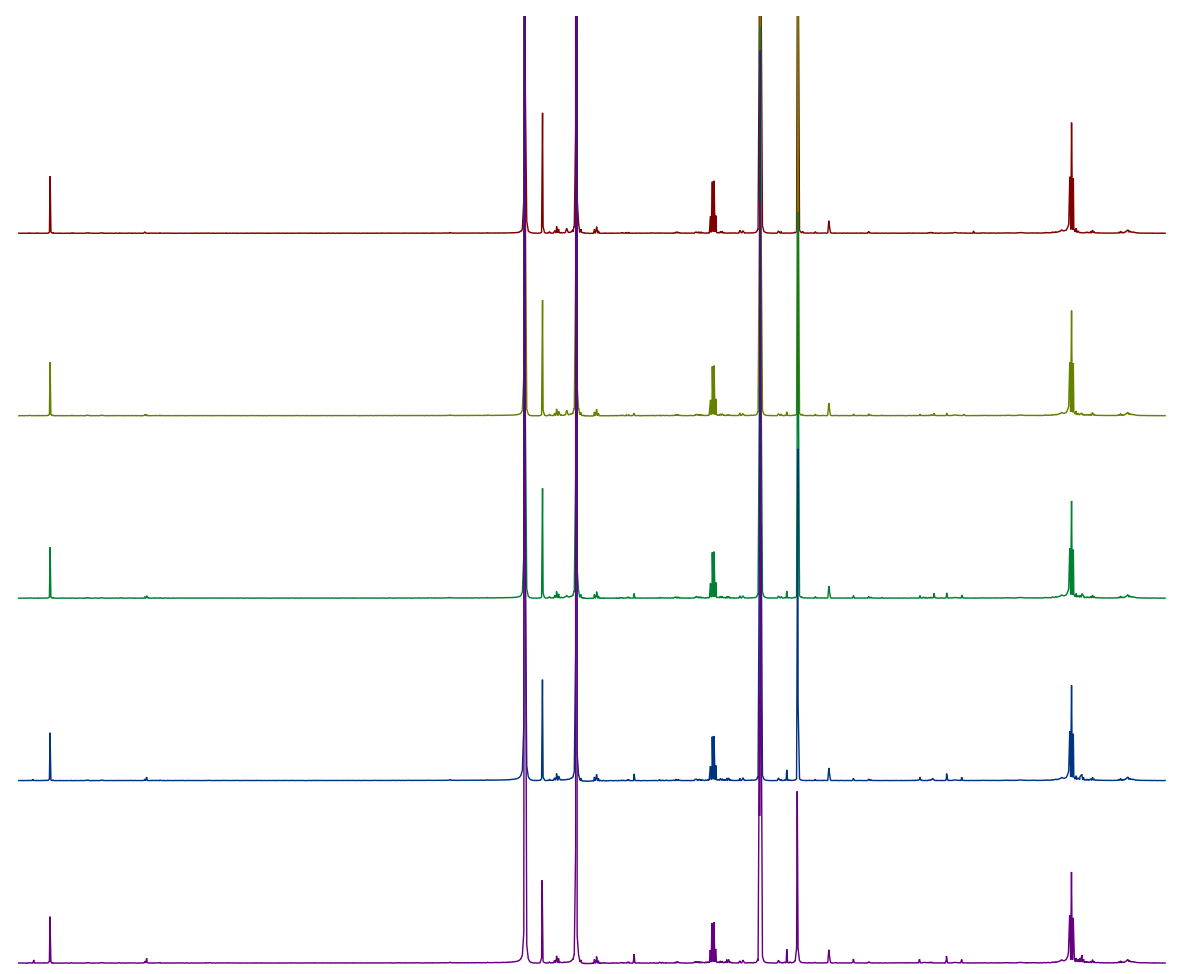

$\begin{array}{lllllllllllllll}8.0 & 7.5 & 7.0 & 6.5 & 6.0 & 5.5 & 5.0 & 4.5 & 4.0 & 3.5 & 3.0 & 2.5 & 2.0 & 1.5 & 1.0\end{array}$ f1 (ppm)

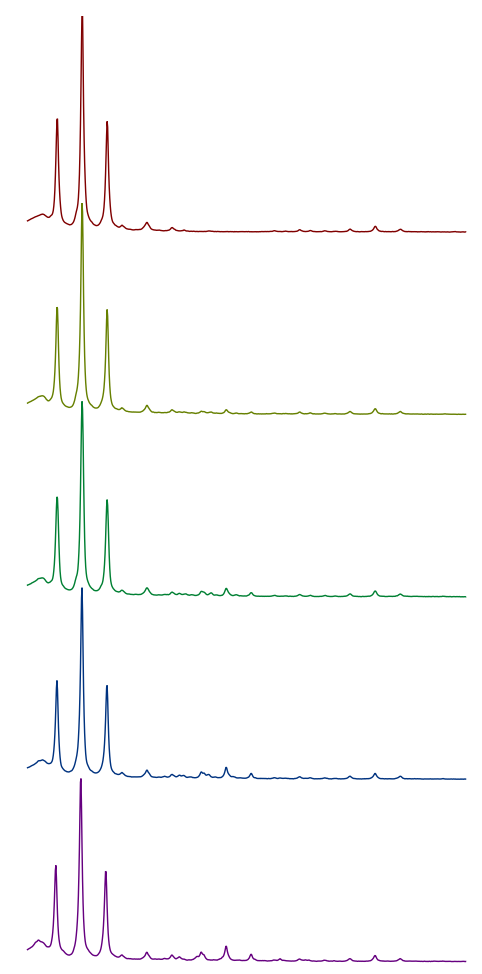

$\begin{array}{llll}1.25 & 1.20 & 1.15 & 1.1\end{array}$ f1 (ppm)

Figure S23: Representative ${ }^{1} \mathrm{H}$ NMR of irradiated 9. Top trace is time $=0$. Increments of 5 min descending. Zoom of leaving group on right. 


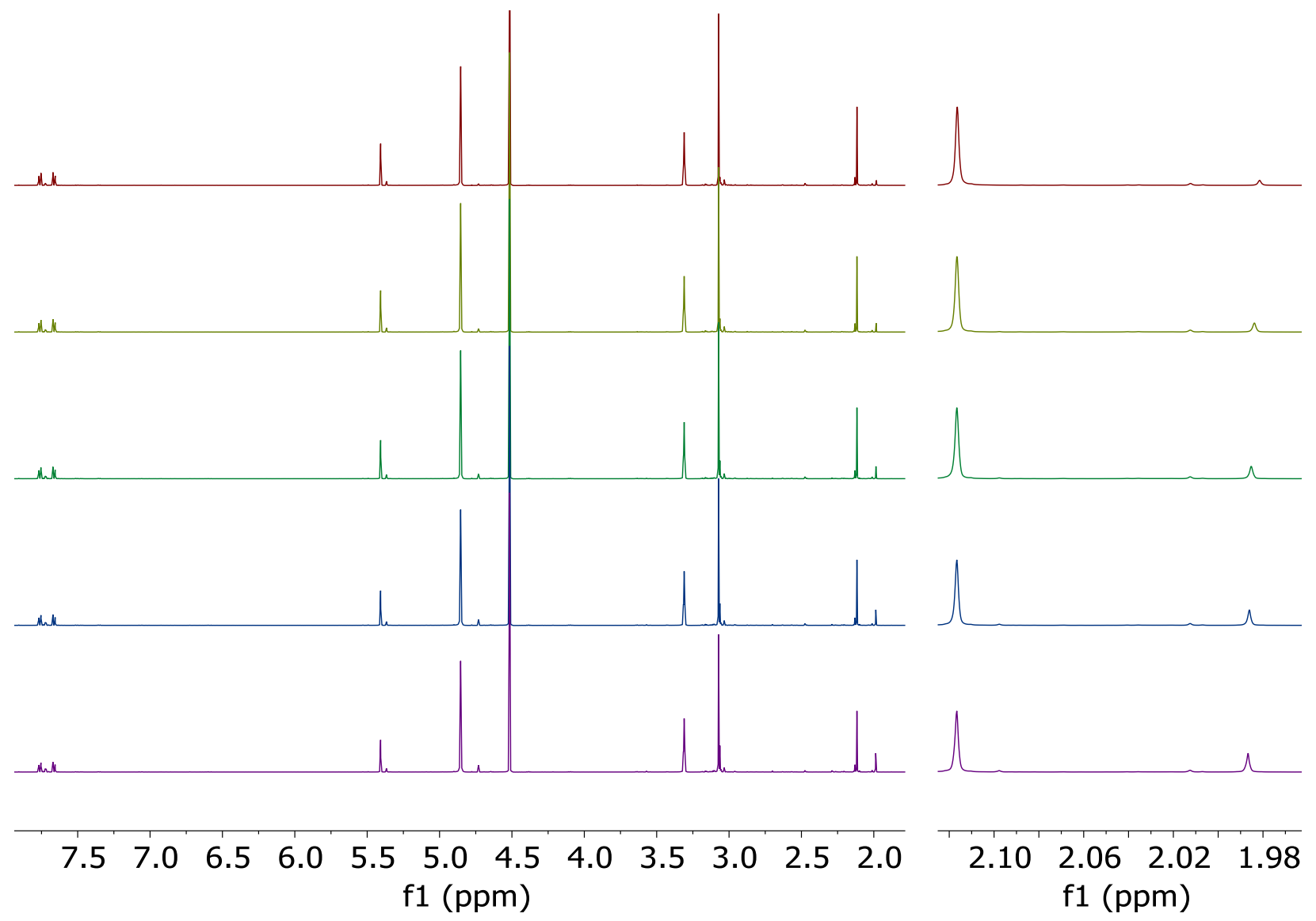

Figure S24: Representative ${ }^{1} \mathrm{H}$ NMR of irradiated 10. Top trace is time $=0$. Increments of $5 \mathrm{~min}$ descending. Zoom of leaving group on right. 


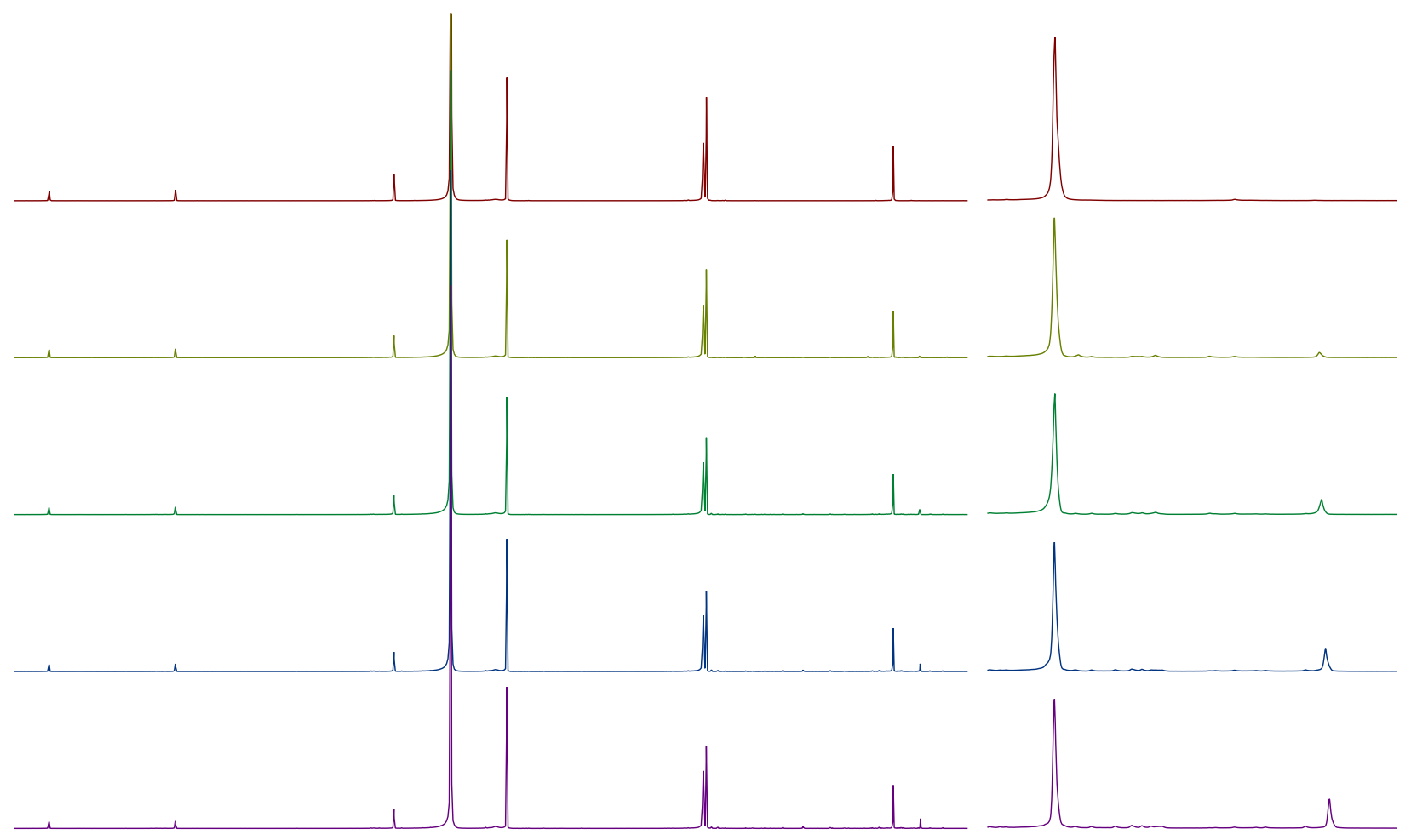

\section{$\begin{array}{llllllllllllllllll}7.5 & 7.0 & 6.5 & 6.0 & 5.5 & 5.0 & 4.5 & 4.0 & 3.5 & 3.0 & 2.5 & 2.0 & & 2.15 & 2.10 & 2.05 & 2.00 & 1.9 !\end{array}$ f1 (ppm) \\ $\mathrm{f1}(\mathrm{ppm})$}

Figure S25: Representative ${ }^{1} \mathrm{H}$ NMR of irradiated 11. Top trace is time $=0$. Increments of $5 \mathrm{~min}$ descending. Zoom of leaving group on right. 


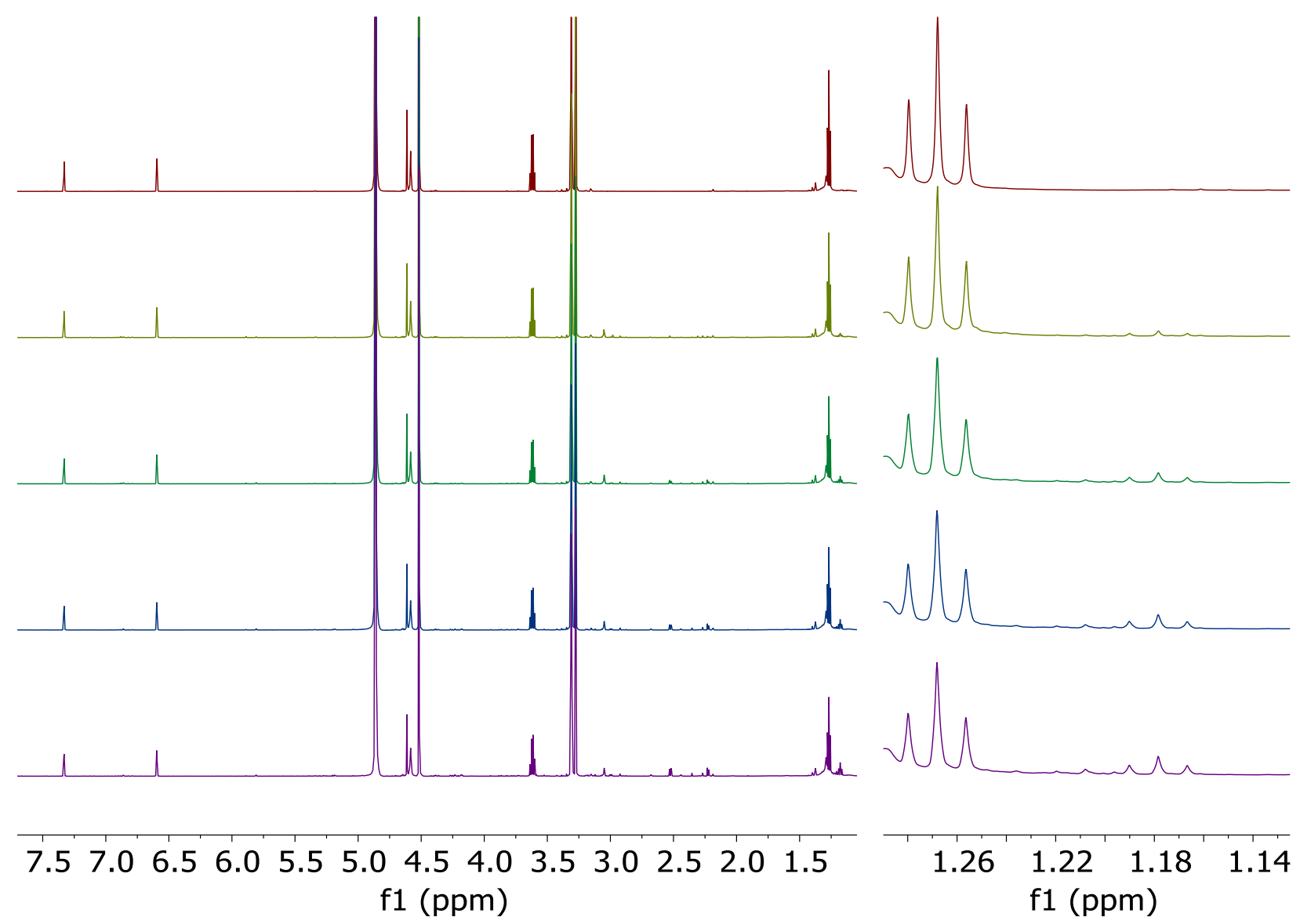

Figure S26: Representative ${ }^{1} \mathrm{H}$ NMR of irradiated 12. Top trace is time $=0$. Increments of $5 \mathrm{~min}$ descending. Zoom of leaving group on right. 


\section{Computed coordinates}

\begin{tabular}{lrrr}
\multicolumn{3}{l}{ Main Text Table 2, Entry 1 } \\
Symbol & X & \multicolumn{2}{l}{} \\
C & -1.372347 & 0.984689 & -0.143877 \\
C & -0.557567 & -0.190035 & 0.095174 \\
C & 0.897216 & -0.088213 & 0.052112 \\
C & 1.414007 & 1.303642 & 0.148633 \\
C & 0.540122 & 2.421386 & -0.233642 \\
C & -0.792851 & 2.288605 & -0.36873 \\
H & 1.01466 & 3.392697 & -0.332115 \\
N & -2.67059 & 0.725862 & -0.1568 \\
N & -1.269368 & -1.306761 & 0.245098 \\
S & -2.851618 & -0.89117 & 0.1243 \\
N & 1.686082 & -1.139408 & -0.104568 \\
C & 2.58994 & 1.576623 & 0.763254 \\
H & 3.230257 & 0.818478 & 1.19762 \\
H & 2.905629 & 2.606601 & 0.901891 \\
C & 3.09311 & -1.064008 & -0.55076 \\
H & 3.771154 & -1.28521 & 0.278869 \\
H & 3.227575 & -1.825464 & -1.322967 \\
H & 3.317736 & -0.083845 & -0.965424 \\
C & 1.204943 & -2.53436 & 0.034076 \\
H & 0.579564 & -2.635243 & 0.917781 \\
H & 0.62124 & -2.822068 & -0.84537 \\
H & 2.080782 & -3.176851 & 0.120996 \\
H & -1.445006 & 3.121795 & -0.603641 \\
& & & \\
Energy & & -911.1356 & Hartrees
\end{tabular}




\section{Main Text Table 2, Entry 2}

\begin{tabular}{lrrrr} 
Symbol & \multicolumn{3}{c}{$\mathrm{Y}$} \\
$\mathrm{C}$ & 1.301282 & 0.840424 & 0.005815 \\
$\mathrm{C}$ & 0.443626 & -0.347631 & 0.001353 \\
$\mathrm{C}$ & -1.018974 & -0.232441 & 0.004151 & \\
$\mathrm{C}$ & -1.504196 & 1.077973 & 0.00519 \\
$\mathrm{C}$ & -0.652261 & 2.235555 & 0.008101 \\
$\mathrm{C}$ & 0.777391 & 2.126846 & 0.009226 \\
$\mathrm{H}$ & -2.568977 & 1.262654 & 0.011288 \\
$\mathrm{H}$ & 1.421234 & 2.999161 & 0.009339 \\
$\mathrm{~N}$ & 2.62409 & 0.550144 & -0.002692 \\
$\mathrm{~N}$ & 1.144797 & -1.475042 & -0.013672 \\
$\mathrm{~S}$ & 2.744977 & -1.059208 & -0.018047 \\
$\mathrm{C}$ & -1.165889 & 3.513381 & 0.014333 \\
$\mathrm{~N}$ & -1.83837 & -1.313609 & -0.003618 \\
$\mathrm{C}$ & -1.362624 & -2.703984 & 0.070061 & \\
$\mathrm{H}$ & -2.233683 & -3.352268 & 0.156305 \\
$\mathrm{H}$ & -0.801274 & -2.985397 & -0.824977 \\
$\mathrm{H}$ & -0.725111 & -2.860917 & 0.942687 \\
$\mathrm{C}$ & -3.283142 & -1.082805 & -0.061937 \\
$\mathrm{H}$ & -3.795493 & -2.041135 & -0.124639 \\
$\mathrm{H}$ & -3.639318 & -0.55828 & 0.833985 \\
$\mathrm{H}$ & -3.549878 & -0.493722 & -0.947642 \\
$\mathrm{H}$ & -0.515047 & 4.383021 & 0.018934 \\
$\mathrm{H}$ & -2.236984 & 3.699845 & 0.015583 \\
& & & & \\
Energy & & -911.1054 & Hartrees
\end{tabular}




\section{ORTEP of 8}

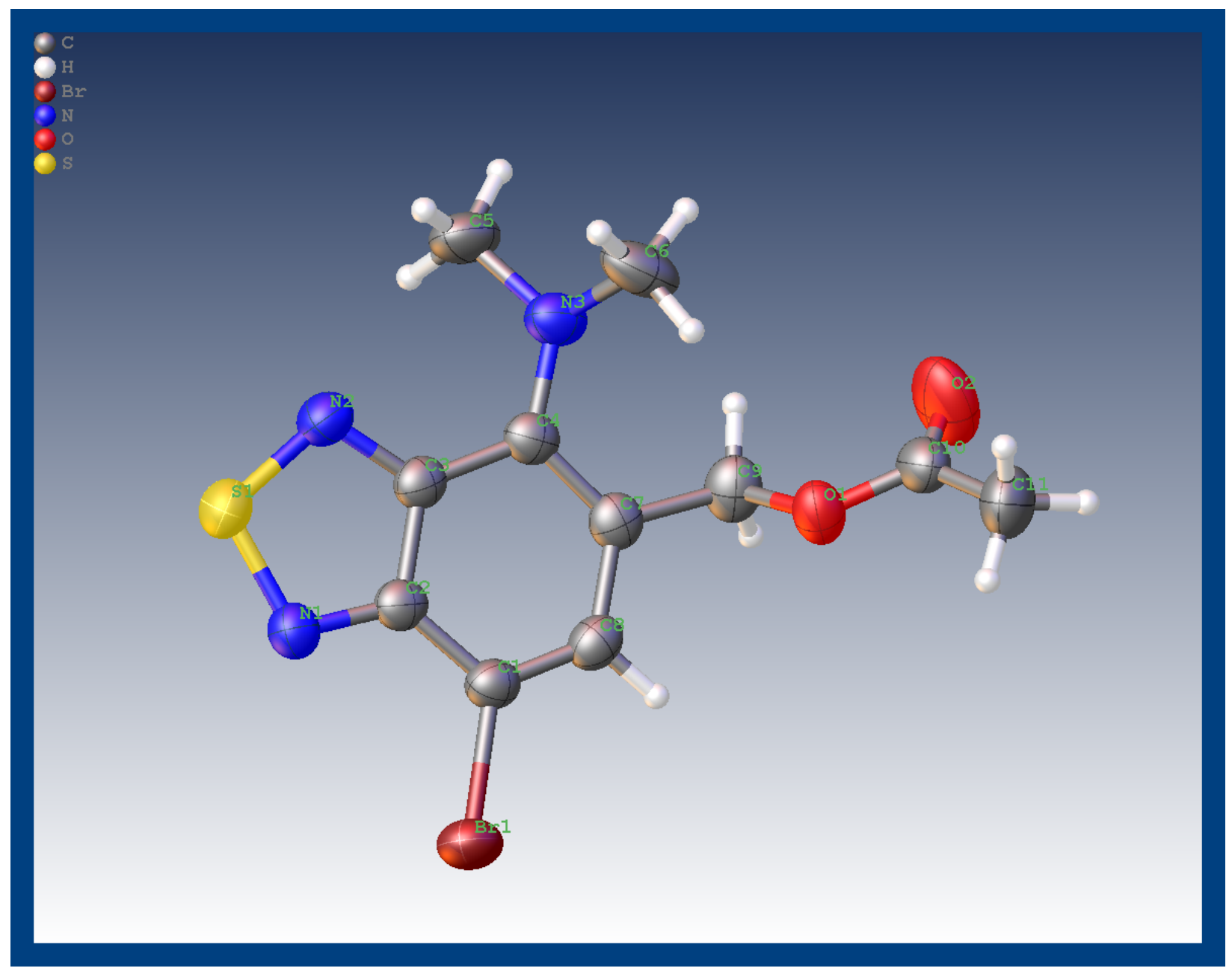




\section{Photophysical Data for Molecules 8-12}

Table S1 - Photophysical data for molecules 8-12.

\begin{tabular}{|ccccccc|c|}
\hline Molecule & $\lambda_{\max }(\mathrm{nm})$ & $\varepsilon\left(\mathrm{M}^{-1} \mathrm{~cm}^{-1}\right)$ & $\log \varepsilon$ & $\Phi_{\mathrm{r}}$ & $\varepsilon \Phi\left(\mathrm{M}^{-1} \mathrm{~cm}^{-1}\right)$ & $\Phi_{\mathrm{f}}$ \\
\hline 8 & 426 & 2143 & 3.331 & 0.028 & 60 & 0.002 \\
\hline 9 & 427 & 1684 & 3.226 & 0.015 & 25 & 0.002 \\
\hline 10 & 400 & 1991 & 3.299 & 0.067 & 133 & 0.001 \\
\hline 11 & 429 & 7926 & 3.899 & 0.061 & 483 & 0.004 \\
\hline 12 & 429 & 3596 & 3.556 & 0.04 & 144 & 0.007 \\
\hline
\end{tabular}

Fluorescence quantum yields were determined relative to coumarin-153 in ethanol (0.54).

\section{UPLC traces of compounds 9 and 12}

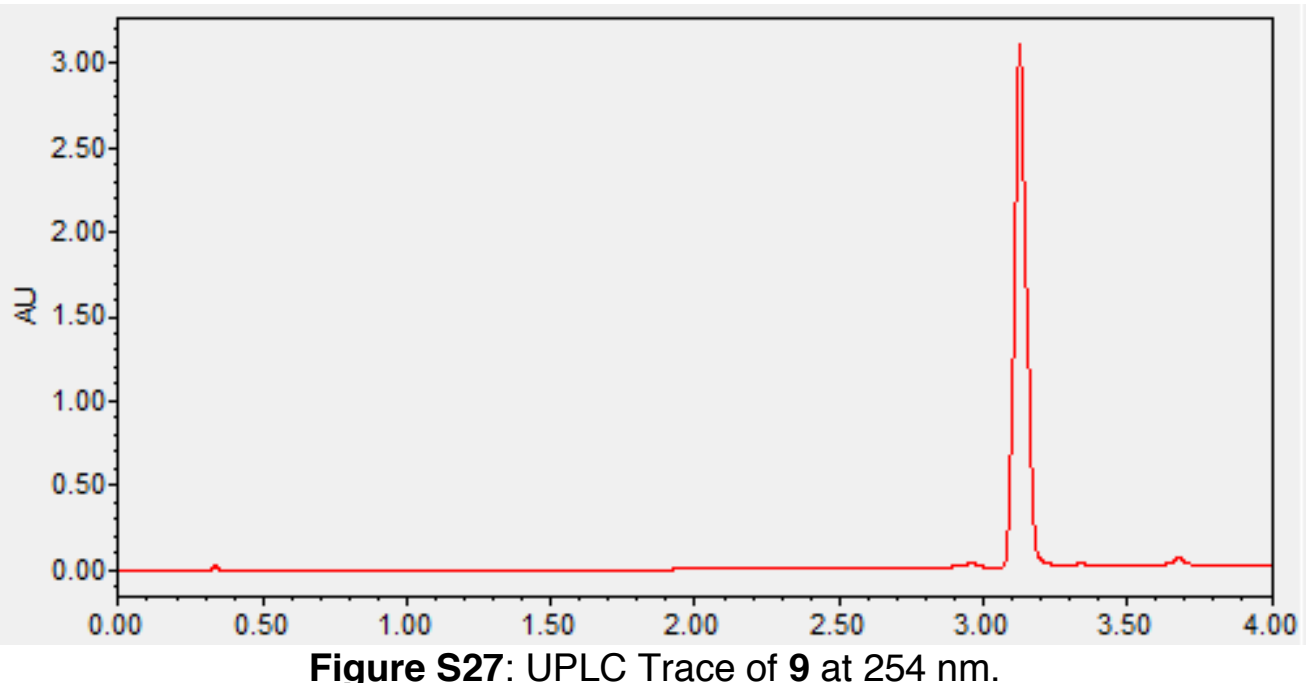

Figure S27: UPLC Trace of 9 at $254 \mathrm{~nm}$. 


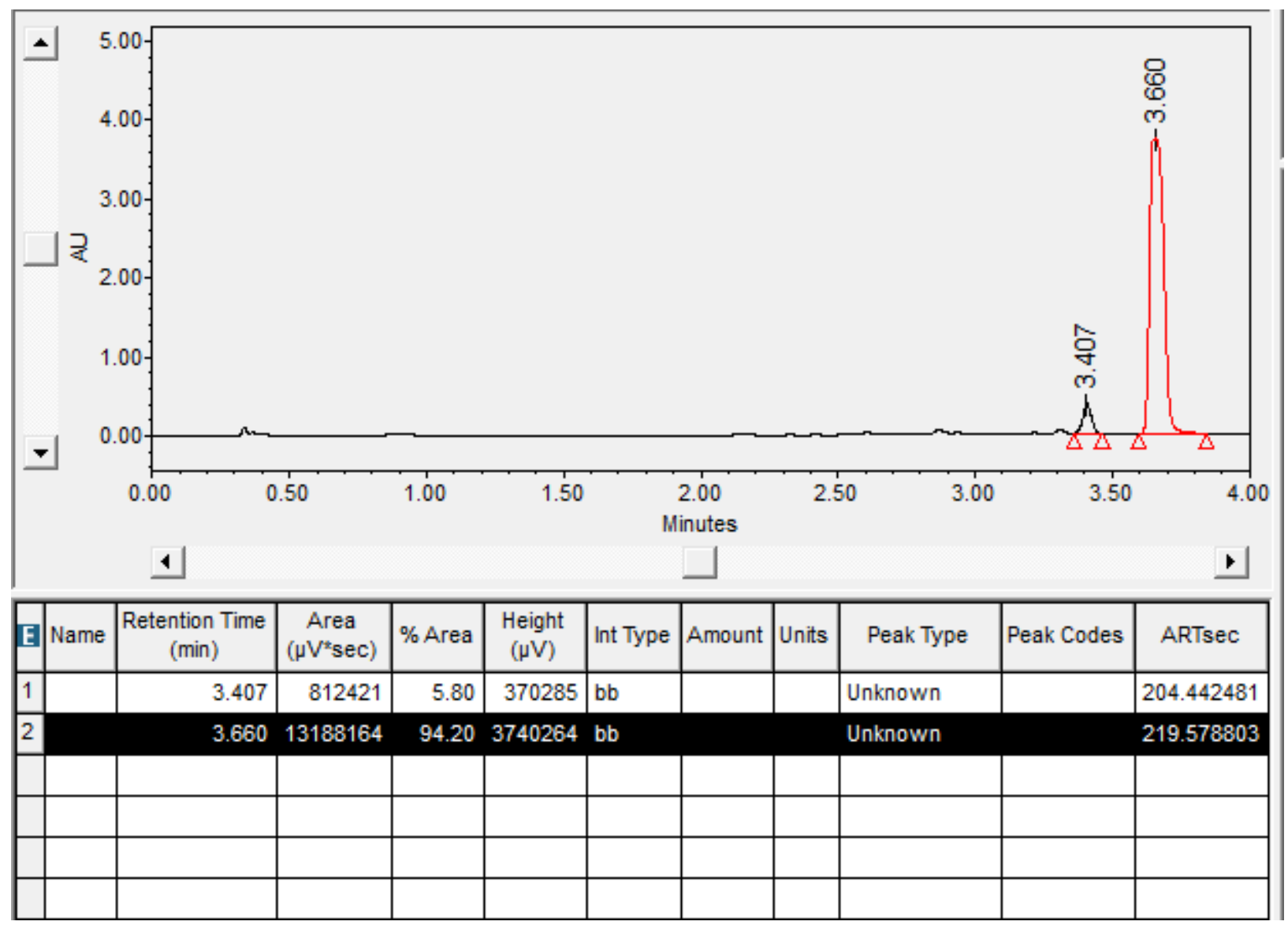

Figure S28: UPLC trace and relative peak integrations for 12. Determined to be 95\% pure based on peak integrations. 


\section{Before and after irradiation data for 10}

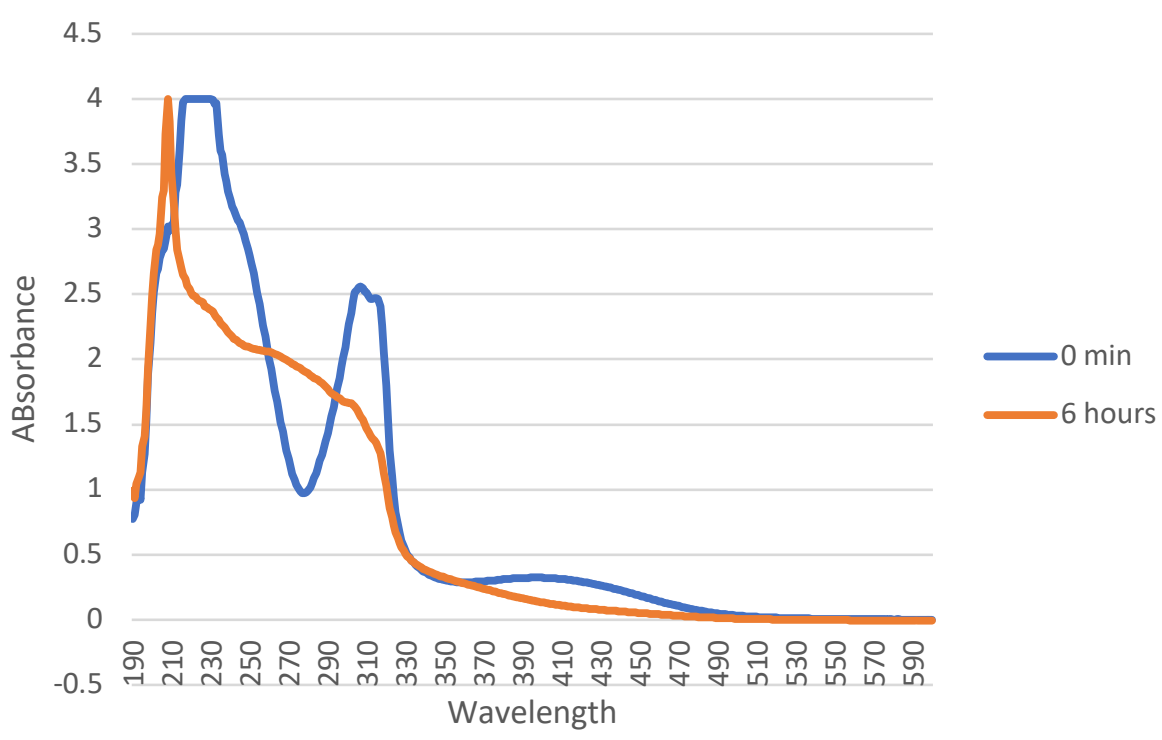

Figure S29: UV-vis absorbance of 10 in methanol before and after irradiation with $455 \mathrm{~nm}$ LED light
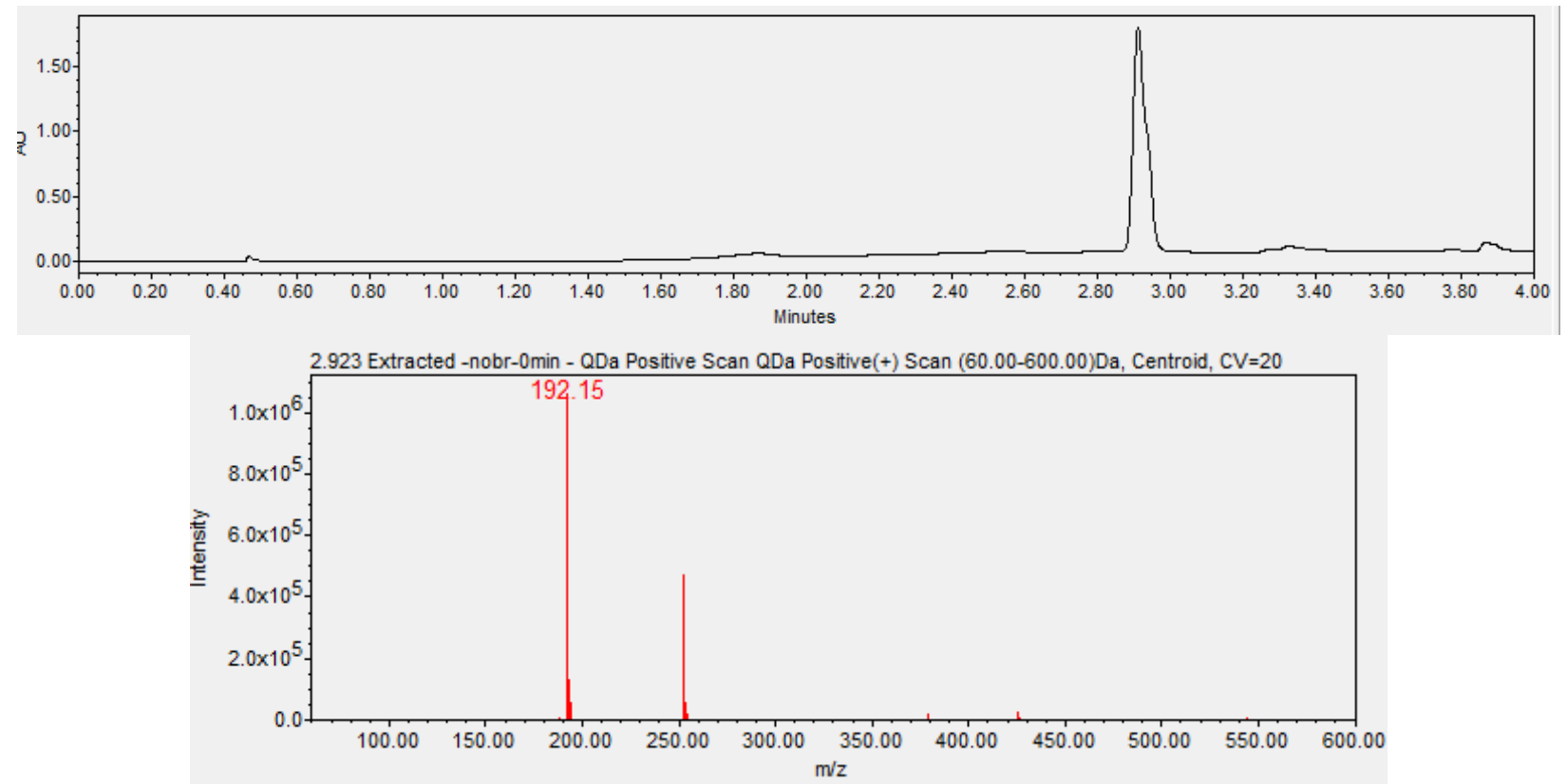

Figure S30: UPLC-MS trace of 10 before irradiation with $455 \mathrm{~nm}$ LED light. Solvent gradient 95:5 water:acetonitrile to 5:95 water:acetonitrile over $4 \mathrm{~min}$. 

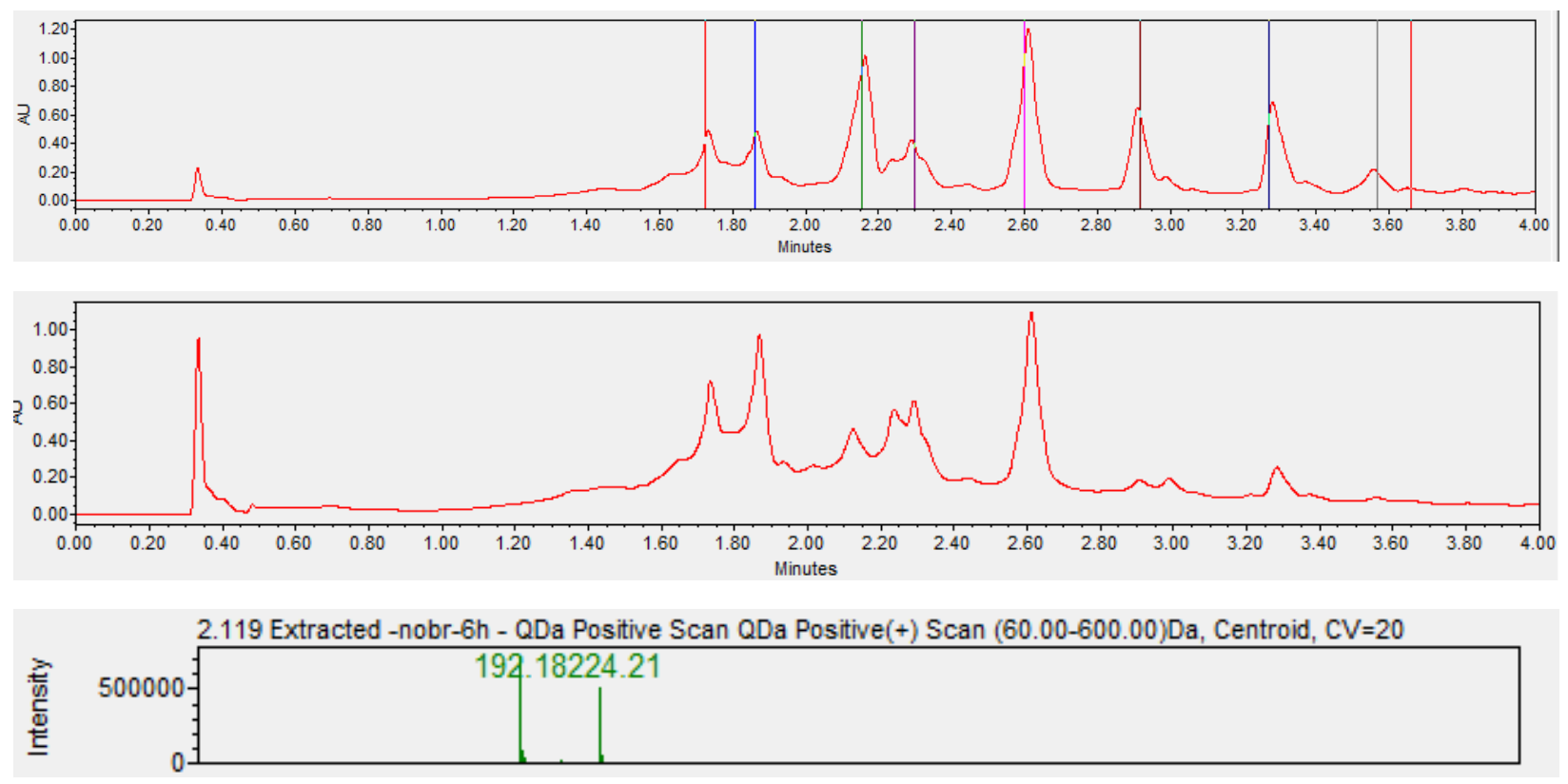

Figure S31: UPLC-MS trace of 10 at $3 \mathrm{~h}$ (top) and $6 \mathrm{~h}$ (bottom) of irradiation with $455 \mathrm{~nm}$ LED light. Solvent gradient 95:5 water:acetonitrile to 5:95 water:acetonitrile over $4 \mathrm{~min}$. The peak at $2.12 \mathrm{~min}$ was assigned as the methanol adduct following elimination of the acetate leaving group (see reaction scheme below). The reaction does not lead to a single photoproduct, which is likely due to photodegradation of the benzothiadiazole core under sustained irradiation.<smiles>C=C1C=Cc2nsnc2C1=NOCc1ccc(S(C)(=O)=O)cc1</smiles> 


\section{REFERENCES}

(1) Sharma, K. S.; Singh, V.; Singh, R. P., 1,2,5-Thiadiazole Derivatives: Part lii - Synthesis \& Substitution Reactions of 4-Bromo-6-Methylbenzo-2,1,3-Tiadiazole \& Its Derivatives. Indian J. Chem. 1978, 16B, 892-894.

(2) Rizzacasa, M. A.; Sargent, M. V., The Synthesis of Stypandrol, a Toxic Binaphthalenetetrol Isolated from Stypandra-Imbricata - New Syntheses of Dianellidin and Stypandrone. Aust J Chem 1988, 41, 1087-1097.

(3) Moriyama, K.; Takemura, M.; Togo, H., Direct and Selective Benzylic Oxidation of Alkylarenes Via C-H Abstraction Using Alkali Metal Bromides. Org Lett 2012, 14, 2414-7.

(4) Ganem, B.; Boeckman, R. K., Silver-Assisted Dimethylsulfoxide Oxidations - Improved Synthesis of Aldehydes and Ketones. Tetrahedron Lett 1974, 917-920.

(5) Bruno, N. C.; Niljianskul, N.; Buchwald, S. L., N-Substituted 2-Aminobiphenylpalladium Methanesulfonate Precatalysts and Their Use in C-C and C-N Cross-Couplings. J Org Chem 2014, 79, 4161-6.

(6) Parker, C. A., A New Sensitive Chemical Actinometer .1. Some Trials with Potassium Ferrioxalate. Proc R Soc Lon Ser-A 1953, 220, 104-116.

(7) Goswami, P. P.; Syed, A.; Beck, C. L.; Albright, T. R.; Mahoney, K. M.; Unash, R.; Smith, E. A.; Winter, A. H., Bodipy-Derived Photoremovable Protecting Groups Unmasked with Green Light. J Am Chem Soc 2015, 137, 3783-6.

(8) Ji, Y.; DiRocco, D. A.; Hong, C. M.; Wismer, M. K.; Reibarkh, M., Facile Quantum Yield Determination Via Nmr Actinometry. Org Lett 2018, 20, 2156-2159. 